Published by IWA Publishing. This is the Author Accepted M anuscript issued with:

Creative Commons Attribution Non-Commercial No Derivatives License (CC:BY:NC:ND 3.0).

\title{
Biogas upgrading by chemical absorption using ammonia rich absorbents derived from wastewater
}

\author{
Andrew McLeod, Bruce Jefferson*, Ewan J. McAdam \\ Cranfield Water Science Institute, Building 39, Cranfield University, Bedfordshire, MK43 OAL, UK \\ *Corresponding author e-mail: b.jefferson@cranfield.ac.uk
}

\begin{abstract}
The use of ammonia $\left(\mathrm{NH}_{3}\right)$ rich wastewaters as an ecological chemical absorption solvent for the selective extraction of carbon dioxide $\left(\mathrm{CO}_{2}\right)$ during biogas upgrading to 'biomethane' has been studied. Aqueous ammonia absorbents of up to $10000 \mathrm{gNH}_{3} \mathrm{~m}^{-3}$ demonstrated $\mathrm{CO}_{2}$ absorption rates higher than recorded in the literature for packed columns using $20000-80000 \mathrm{gNH}_{3} \mathrm{~m}^{-3}$ which can be ascribed to the process intensification provided by the hollow fibre membrane contactor used in this study to support absorption. Centrifuge return liquors ( $2325 \mathrm{~g} \mathrm{~m}^{-3}$ ionised ammonium, $\mathrm{NH}_{4}{ }^{+}$) and a regenerant $\left(477 \mathrm{gNH}_{4}^{+} \mathrm{m}^{-3}\right)$ produced from a cationic ion exchanger used to harvest $\mathrm{NH}_{4}^{+}$from crude wastewater were also tested. Carbon dioxide fluxes measured for both wastewaters compared reasonably with analogue ammonia absorption solvents of equivalent $\mathrm{NH}_{3}$ concentration. Importantly, this demonstrates that ammonia rich wastewaters can facilitate chemically enhanced $\mathrm{CO}_{2}$ separation which eliminates the need for costly exogenic chemicals or complex chemical handling which are critical barriers to implementation of chemical absorption. When testing $\mathrm{NH}_{3}$ analogues, the potential to recover the reaction product ammonium bicarbonate $\left(\mathrm{NH}_{4} \mathrm{HCO}_{3}\right)$ in crystalline form was also illustrated. This is significant as it suggests a new pathway for ammonia separation which avoids biological nitrification and produces ammonia stabilised into a commercially viable fertiliser $\left(\mathrm{NH}_{4} \mathrm{HCO}_{3}\right)$. However, in real ammonia rich wastewaters, sodium bicarbonate and calcium carbonate were preferentially formed over $\mathrm{NH}_{4} \mathrm{HCO}_{3}$ although it is proposed that $\mathrm{NH}_{4} \mathrm{HCO}_{3}$ can be preferentially formed by manipulating both ion exchange and absorbent chemistry.
\end{abstract}

Keywords: carbon dioxide sequestration; crystallisation; gas/liquid contactor; chemical scrubbing 


\section{Introduction}

Biogas produced through the anaerobic digestion of sewage sludge can be exploited either through co-generation for electricity and heat production (CHP) or it can be upgraded to natural gas standards (biomethane). Due to recently introduced financial incentives the revenue from biomethane can be up to $70 \%$ higher than for electricity production (Read and Hofmann, 2011). Whilst trace biogas impurities, such as hydrogen sulfide $\mathrm{H}_{2} \mathrm{~S}$ and particulates, are routinely removed (e.g. by activated carbon) prior to further biogas utilisation (Rautenbach and Welsch, 1994); upgrading to produce biomethane requires additional removal of the bulk $\mathrm{CO}_{2}$ fraction to increase methane content to the equivalent of natural gas and is most commonly undertaken by absorption (Persson et al., 2007). This represents a new unit process operation to the water industry, although the same separation technology has seen extensive investigation for deployment into carbon capture and storage (CCS). In CCS, chemical absorption is applied in a packed column which mediates contact between the $\mathrm{CO}_{2}$ rich gas and a highly reactive chemical solvent such as monoethanolamine (MEA) that is selective for $\mathrm{CO}_{2}$ and offers high absorption capacities of around $0.55 \mathrm{~kg} \mathrm{CO}_{2} \mathrm{kgMEA}^{-1}$ (Mani et al., 2006). However, a high specific energy demand for solvent regeneration, in addition to chemical losses due to persistent solvent degradation, and associated costs have largely hindered uptake of chemical absorption by water utilities implementing biogas upgrading. Instead, physical absorption using a water solvent is favoured, despite requiring larger absorption columns and higher liquid consumption due to a lower overall mass transfer coefficient (Patterson et al., 2011).

Aqueous free ammonia $\left(\mathrm{NH}_{3}\right)$ has been identified as an alternate chemical absorbent pathway to organic chemicals (e.g. MEA) for CCS as it does not degrade, it is not corrosive and it requires up to $75 \%$ less energy than MEA for regeneration due to weaker bonding of $\mathrm{CO}_{2}$ to ammonia (Budzianowski, 2011a). Furthermore, aqueous ammonia provides an absorption capacity of $1.76 \mathrm{kgCO}_{2} \mathrm{kgNH}_{3}^{-1}$ which is around three times higher than the capacity (by mass) of MEA and is only one sixth of the cost (Mani et al., 2006; Makhloufi et al., 2014). Aqueous ammonia therefore 
presents analogous opportunities for biogas upgrading where the gas phase is characterised by a higher $\mathrm{CO}_{2}$ mole fraction than in CCS. Budzianowski (2011b) suggested that ecological solvents rich in ammonium offered potential for exploitation in biogas upgrading. At wastewater treatment works, sludge liquors comprise ammonium concentrations ranging 500 to $2000 \mathrm{mgNH}_{4}{ }^{+} \mathrm{L}^{-1}$ (0.2\% wt.) (Thornton et al., 2007) although ammonium concentrations up to $10000 \mathrm{mgNH}_{4}^{+} \mathrm{L}^{-1}$ (1\% wt.) have been achieved using zeolites to harvest and concentrate ammonium from dilute wastewaters (Mackinnon et al., 2003). Whilst this is an attractive route to chemical cost reduction for water utilities undertaking biogas upgrading, this concentration range is below the 8 to $10 \%$ wt. range commonly applied to aqueous ammonia $\mathrm{CO}_{2}$ absorption in packed columns (Puxty et al., 2010; Shuangchen et al., 2013; Budzianowski, 2011b) which suggests that ecological solvents may offer less favourable enhancement of absorption.

The key disadvantage of aqueous ammonia solvents is that the high saturated vapour pressure introduces $\mathrm{NH}_{3}$ slip into the gas phase, where outlet flue gas concentrations of up to 2000 ppmv $\mathrm{NH}_{3}$ have been reported (Kozak, 2009). This requires ammonia washing abatement equipment at the outlet of the absorption column which will influence both capital cost and energy demand (Shuangchen et al., 2013). Budzianowski (2011b) proposed that $\mathrm{NH}_{3}$ slip could be diminished through the introduction of hollow fibre membrane contactor (HFMC) technology as an alternative absorption process to conventional packed columns. Rather than enabling direct contact between the gas and liquid phase as with conventional columns, the hydrophobic membrane in the HFMC supports non-dispersive contact between gas and liquid phase with gases free to diffuse through the micropores. Porous membranes are resilient to common biogas impurities (i.e. $\mathrm{H}_{2} \mathrm{~S}$ ) and may even combine removal with upgrading if necessary since the acid gas does not permeate through the polymer (Rongwong et al., 2012). HFMC therefore present an opportunity to exploit the key advantages of aqueous ammonia absorption for biogas upgrading whilst also diminishing $\mathrm{NH}_{3}$ slip. The high specific surface area (around $3000 \mathrm{~m}^{2} \mathrm{~m}^{-3}$ ) in HFMCs also provides greater process intensification when compared to packed columns (around $300 \mathrm{~m}^{2} \mathrm{~m}^{-3}$ ) reducing both process scale 
and absorption solvent consumption (Makhloufi et al., 2014). For instance, Nii and Takeuchi (1992) compared HFMC technology with packed columns for chemical absorption and noted an order of magnitude reduction in absorbent solvent flow rate required to achieve analogous $\mathrm{CO}_{2}$ separation from flue gas. It is therefore proposed that the enhanced absorbent utilisation afforded by HFMC technology could enable the practicable use of lower concentration ecological solvents for chemical cost reduction.

Absorption and reaction of $\mathrm{CO}_{2}$ into aqueous ammonia is complex with both $\mathrm{NH}_{3}$ and $\mathrm{CO}_{2}$ undergoing multiple liquid phase reactions (Mani et al., 2006; Budzianowski, 2011a). However, several authors have cited the potential of this process for the production and recovery of the key reaction product ammonium bicarbonate $\left(\mathrm{NH}_{4} \mathrm{HCO}_{3}\right)$ which has a commercial value of around $€ 111$ tonne $^{-1}$ (Budzianowski, 2011b; Hernandez et al., 2013). This is particularly attractive for biogas upgrading using ammonia rich wastewater as the chemical solvent since stabilisation of ammonium into the reaction product circumvents the need for direct biological treatment of ammonium in the wastewater. The following investigation therefore aims to establish the suitability of ammonia rich wastewater as a chemical solvent for biogas upgrading using HFMC technology as the underpinning absorption process. Specifically, this study seeks to: (i) quantify the chemical absorption potential of low concentration (environmentally relevant) aqueous ammonia solvents for $\mathrm{CO}_{2}$ separation; (ii) determine the reactivity of real ammonia rich wastewaters compared to exogenic ammonia absorbents of equal concentration; (iii) measure the volatility of $\mathrm{NH}_{3}$ into the gas phase within appropriate absorbent and process boundary conditions; and (iv) establish the feasibility of recovering the favoured reactant product $\mathrm{NH}_{4} \mathrm{HCO}_{3}$.

\section{Materials and methods}

\subsection{Equipment setup and operation}

Synthetic biogas was prepared using mass flow controllers $\left(0.01-1.0 \mathrm{~L} \mathrm{~min}{ }^{-1}\right.$, Roxspur Measurement and Control Ltd., Sheffield, UK) to mix methane (99.995\%) and carbon dioxide (99.7 \%) (BOC gases, 
Ipswich, UK) in-line at a typical flow rate $750 \mathrm{~mL} \mathrm{~min}^{-1}$ (2.5 s HFMC residence time) to provide a 60:40 / $\mathrm{CH}_{4}: \mathrm{CO}_{2}$ gas which was supplied into the hollow fibre membrane lumen. The HFMC comprised 7400 polypropylene fibres each with an outer diameter and length of $300 \mu \mathrm{m}$ and 0.113 $\mathrm{m}$ respectively (total surface area $0.79 \mathrm{~m}^{2}$, Membrana $\mathrm{GmbH}$, Wuppertal, Germany). The fibres comprised a $0.03 \mu \mathrm{m}$ nominal pore size and $40 \%$ porosity with a packing density of 0.369 (Fig. 1a). Absorbent was stored in a 10 L PVC tank, maintained at $19-21{ }^{\circ} \mathrm{C}$ by a thermostatic water bath (GD120, Grant Instruments Cambridge Ltd., Shepreth, UK) and was passed through the HFMC shell, in counter-current mode using a centrifugal pump (max. $6 \mathrm{~L} \mathrm{~min}{ }^{-1}, 50010$ series, Jabsco $\mathrm{GmbH}$, Norderstedt, Germany) at a typical flow rate of $100 \mathrm{~mL} \mathrm{~min}^{-1}$ (60 s hydraulic residence time). Ammonia slip in to the gas phase was determined by the method described by Kuntke et al. (2012). The out-gas was bubbled through diffusers in two $1 \mathrm{~L}$ capacity gas tight aspirator bottles (Schott Duran, VWR, The Netherlands) in series, containing $500 \mathrm{~mL}$ of $0.4 \mathrm{~mol} \mathrm{~L}^{-1}$ sulphuric acid; the second bottle enabling verification of breakthrough from the first.

The ion exchanger comprised a $10 \mathrm{~L}$ column containing 4 I of clinoptilolite resin (RS Minerals, Guisborough, UK) and was prepared by passing a $50 \mathrm{~g}_{\mathrm{NaCl}} \mathrm{L}^{-1}(99 \%$, Fisher Chemicals, Loughborough, UK) regenerant through the column at 5 bed volumes per hour $\left(B v h^{-1}\right)$ for 30 minutes followed by a DI rinse at $5 \mathrm{Bv} \mathrm{h}^{-1}$ for 60 minutes (McAdam et al., 2010) (Fig. 1b). The column was operated in down-flow using crude sewage $\left(10-20 \mathrm{gNH}_{4}{ }^{+} \mathrm{m}^{-3}\right.$ ) at $4.2 \mathrm{Bv} \mathrm{h}^{-1}$ (Aiyuk et al., 2004) until breakthrough which was noted at $166 \mathrm{Bv}$. The column was regenerated using $20 \mathrm{~L}_{\text {of }} 50 \mathrm{~g}_{\mathrm{NaCl}} \mathrm{L}^{-1}$ at $1 \mathrm{BV} \mathrm{h}^{-1}$. The IEX regenerant was filtered through a $1.2 \mu \mathrm{m}$ filter (GF/C $15 \mathrm{~mm}$, Fisher Scientific, Loughborough, UK) prior to use. Return liquor was collected from a digestate dewatering centrifuge at a local WWTW and was filtered through a 6-12 $\mu \mathrm{m}$ filter before centrifugation (Sorvall Legend RT+, Thermo Fisher Scientific, Hemel Hempstead, UK) at 5000 rpm for 10 minutes with the decant filtered through a 1.2 $\mu \mathrm{m}$ filter.

\subsection{Chemical preparation, sampling and analysis}


Analogue absorbents were freshly prepared by adding saturated aqueous ammonia solution (35\%, 2.5 L, Fisher Chemicals) to DI water. Ammonia concentration was confirmed by ammonium cell test. The $\mathrm{pH}$ of real and synthetic absorbents was fixed at $\mathrm{pH} 11$ (excluding variable $\mathrm{pH}$ experiments). Aqueous ammonia analysis was undertaken using cell tests (VWR International Ltd., Poole, UK) with photometric determination using a Spectroquant Nova 60 (Merck-Millipore, Darnstadt, Germany). Gas composition after the HFMC was determined using an infrared biogas analyser (Yieldmaster, accuracy $<0.2 \%$ full-scale, Bluesens gas sensor $\mathrm{GmbH}$, Herten, Germany). Gas flow rate was measured using a bubble flow meter (50 mL, Restek, Bellefonte, USA). Flux $\left(J_{\text {CO2 }}, \mathrm{mol} \mathrm{m}^{-2} \mathrm{~s}^{-1}\right)$ was calculated using:

$J_{C O 2}=\frac{\left\lfloor\left(Q_{G, \text { in }} x C_{G, \text { in }}\right)-\left(Q_{G, \text { out }} x C_{G, \text { out }}\right)\right\rfloor \times 273.15 \times 1000}{\left(22.4 x A_{m} x T_{c}\right)}$ (Equation 1)

where $Q_{G, \text { in }}$ and $Q_{G \text {, out }}$ are gas flow rate before and after HFMC respectively $\left(m^{3} s^{-1}\right), c_{G}$, in and $c_{G \text {, out }}$ are the $\mathrm{CO}_{2}$ content before and after HFMC respectively (mol mol$\left.{ }^{-1}\right), \mathrm{A}_{\mathrm{m}}$ refers to the membrane surface area for absorption $\left(\mathrm{m}^{2}\right)$ and $\mathrm{T}_{\mathrm{G}}$ is the gas temperature (K) (Atchariyawut et al., 2007). The enhancement in flux provided by the chemical reactivity of the absorbent was characterised using the 'enhancement factor' $(E)$ which can be applied providing an identical driving force for mass transfer is assumed (Dindore et al., 2005):

$$
E=\frac{\mathrm{CO}_{2} \text { flux }(\text { chemical })}{\mathrm{CO}_{2} \text { flux }(\text { physical })}
$$

Microscopy of membrane fibres and crystals was performed by scanning electron microscope (SEM, XL30, FEI, Hillsboro, Oregon, USA)), energy dispersive x-ray spectroscopy (EDX, Oxford Instruments NTS, Abingdon, UK) and x-ray diffraction (XRD, D5005, Siemens, Munich, Germany).

\subsection{Liquid phase chemical reactions of $\mathrm{CO}_{2}$ and aqueous ammonia}

The following chemical reactions are known to take place during chemical absorption of $\mathrm{CO}_{2}$ into aqueous ammonia (Puxty et al., 2012; Niu et al., 2012): 


$$
\begin{array}{lr}
\mathrm{CO}_{2}+\mathrm{H}_{2} \mathrm{O} \leftrightarrow \mathrm{HCO}_{3}^{-} & \text {(Equation 3) } \\
\mathrm{CO}_{3}^{2-}+\mathrm{H}^{+} \leftrightarrow \mathrm{HCO}_{3}^{-} & \text {(Equation 4) } \\
\mathrm{NH}_{3}+\mathrm{H}^{+} \leftrightarrow \mathrm{NH}_{4}^{+} & \text {(Equation 5) } \\
\mathrm{CO}_{2}+\mathrm{NH}_{3} \leftrightarrow \mathrm{NH}_{2} \mathrm{COO}^{-}+\mathrm{H}^{+} & \text {(Equation 6) } \\
\mathrm{NH}_{2} \mathrm{COO}^{-}+\mathrm{H}_{2} \mathrm{O} \leftrightarrow \mathrm{NH}_{3}+\mathrm{HCO}_{3}^{-} & \text {(Equation 7) } \\
\mathrm{NH}_{4} \mathrm{HCO}_{3}(\mathrm{~s}) \leftrightarrow \mathrm{NH}_{4}^{+}+\mathrm{HCO}_{3}^{-} & \text {(Equation 8) }
\end{array}
$$

The ammonium-ammonia equilibrium can be driven toward free ammonia $\left(\mathrm{NH}_{3}\right.$, Equation 5) by increasing absorbent $\mathrm{pH}$ (SM 1). Carbon dioxide reacts with either water to form bicarbonate (Equation 3) or free ammonia to form carbamate $\left(\mathrm{NH}_{2} \mathrm{COO}^{-}\right)$(Equation 6).

\section{Results}

\subsection{Assessment of $\mathrm{CO}_{2}$ absorption using analogue ammonia absorbents}

An increase in solvent $\mathrm{pH}$ under fixed hydrodynamic conditions notably increased $J_{\mathrm{CO} 2}$ at higher free ammonia concentrations (Fig. 2). For example, $J_{C O 2}$ increased from $0.14 \times 10^{-4} \mathrm{~mol} \mathrm{~m}^{-2} \mathrm{~s}^{-1}$ at $\mathrm{pH} 8(20$ ${ }^{\circ} \mathrm{C}$ ) to $0.26 \times 10^{-4} \mathrm{~mol} \mathrm{~m}^{-2} \mathrm{~s}^{-1}$ at $\mathrm{pH} 11\left(20^{\circ} \mathrm{C}\right)$. An increase in $\mathrm{pH}$ drives the ammoniacal nitrogen $\left(\left[\mathrm{NH}_{4}^{+}\right]\right.$ $+\left[\mathrm{NH}_{3}\right], \mathrm{NH}_{4}-\mathrm{N}$ ) equilibrium toward free ammonia with around $15 \%, 90 \%$ and $99 \%$ present as free ammonia at $\mathrm{pH} 8,10$ and 11 respectively at $20^{\circ} \mathrm{C}$ (SM 1, Equation 5). Initial aqueous ammonia concentration also positively increased $J_{\mathrm{CO} 2}$ with a flux of $0.7 \times 10^{-4} \mathrm{~mol} \mathrm{~m}^{-2} \mathrm{~s}^{-1}$ recorded in $10 \mathrm{~g} \mathrm{~m}^{-3}$ $\mathrm{NH}_{3}$ solution compared to $0.38 \times 10^{-4} \mathrm{~mol} \mathrm{~m}^{-2} \mathrm{~s}^{-1}$ in $10000 \mathrm{~g} \mathrm{~m}^{-3} \mathrm{NH}_{3}$ solution operated under identical boundary conditions $\left(\mathrm{pH} 11,20^{\circ} \mathrm{C}\right)$. However, absorbent temperature did not markedly change $J_{\mathrm{CO} 2}$ except for the most concentrated solvent tested $\left(10000 \mathrm{gNH}_{3} \mathrm{~m}^{-3}\right)$.

At a G/L of 0.075 , the $\mathrm{CH}_{4}$ composition of the outlet gas phase was between $98 \%$ and $99 \%$ for the $5000 \mathrm{gNH}_{3} \mathrm{~m}^{-3}$ and $10000 \mathrm{gNH}_{3} \mathrm{~m}^{-3}$ absorbents (Fig. 3a). Upon increasing $\mathrm{Q}_{\mathrm{G}}$ (with a fixed $\mathrm{Q}_{\mathrm{L}}$, 6.7 $\times 10^{-6} \mathrm{~m}^{3} \mathrm{~s}^{-1}$ ), biogas $\mathrm{CH}_{4}$ composition decreased which was more evident for the higher concentration ammonia absorbents. However, $J_{C O 2}$ increased as $Q_{G}$ and with higher fluxes noted 
when using the more concentrated $\mathrm{NH}_{3}$ absorbents (Fig. 3b). At the maximum hydrodynamic conditions tested (G/L 4.2), $J_{\mathrm{CO} 2}$ were $0.94 \times 10^{-4} \mathrm{~mol} \mathrm{~m}^{-2} \mathrm{~s}^{-1}$ for the 10 and $100 \mathrm{gNH}_{3} \mathrm{~m}^{-3}$ absorbents and $1.7 \times 10^{-4} \mathrm{~mol} \mathrm{~m}^{-2} \mathrm{~s}^{-1}$ and $2.3 \times 10^{-4} \mathrm{~mol} \mathrm{~m}^{-2} \mathrm{~s}^{-1}$ for the 5000 and $10000 \mathrm{gNH}_{3} \mathrm{~m}^{-3}$ ammonia absorbents respectively.

\subsection{Measurement of ammonia volatility within process boundary conditions}

The loss of ammonia into the gas phase (or $\mathrm{NH}_{3}$ slip) was ostensibly a function of initial aqueous ammonia concentration when $Q_{L}$ and $Q_{G}$ were fixed at $1.67 \times 10^{-6} \mathrm{~m}^{3} \mathrm{~s}^{-1}$ and $1.25 \times 10^{-5} \mathrm{~m}^{3} \mathrm{~s}^{-1}$ respectively at constant $\mathrm{pH}(11)$ and solvent temperature $\left(20{ }^{\circ} \mathrm{C}\right)$ (Fig. 4). At an aqueous $\mathrm{NH}_{3}$ absorbent concentration of $10000 \mathrm{~g} \mathrm{~m}^{-3}$, which has been achieved in ecological absorbents through concentrating ammonia using ion exchange (Mackinnon et al., 2003), an $\mathrm{NH}_{3}$ concentration of only $0.002 \mathrm{gNH}_{3} \mathrm{~m}^{-3}$ was measured in the treated gas phase. This is below the proposed UK standard for gas phase ammonia in gas to grid applications (dashed line) (Environment Agency, 2013). Niu et al. (2012) also noted $\mathrm{NH}_{3}$ slip was dependent on initial $\mathrm{NH}_{3}$ concentration when testing ammonia absorbents within the same concentration range for $\mathrm{CO}_{2}$ separation from a packed column. However, the observed losses were considerably higher than noted in this study.

\subsection{Efficacy of real ammonia rich wastewaters to deliver enhanced $\mathrm{CO}_{2}$ absorption}

Return liquor and IEX regenerant were prepared and characterised (Table 2). For both of the real absorbents tested, chemical enhancement was maximised at the highest $\mathrm{G} / \mathrm{L}$ ratio imposed (Fig. 5). A maximum $E$ of 14.9 and 2.9 were determined for the return liquor $\left(2325 \mathrm{gNH}_{3} \mathrm{~m}^{-3}\right.$ ) and IEX regenerant $\left(447 \mathrm{gNH}_{3} \mathrm{~m}^{-3}\right)$ respectively at a $\mathrm{G} / \mathrm{L}$ of 37.5 . However, $E$ reduced sharply following a decrease in $\mathrm{G} / \mathrm{L}$ ratio toward an $\mathrm{E}$ of 1 which is comparable to the $J_{\mathrm{CO} 2}$ measured with DI water as the physical absorption solvent. Enhancement factors produced from the real wastewaters were compared to those measured with analogue ammonia absorbents using the same boundary conditions (Fig. 6a and 6b). The enhancement factor for the return liquor was broadly in agreement 
with that determined for the analogue. The chemical enhancement of the IEX regenerant was characterised by a gradient similar to the parity line (where $E_{\text {real }} / E_{s y n}=1$ ) but was below that predicted based on the analogue.

\subsection{Identifying the reaction products formed in real absorbents}

In a preliminary assessment, synthetic biogas was bubbled through an $85000 \mathrm{~g}_{\mathrm{NH} 3} \mathrm{~m}^{-3}$ analogue $\mathrm{NH}_{3}$ solution and within a short time frame a solid $\mathrm{NH}_{4} \mathrm{HCO}_{3}$ product was produced in situ which displayed regularly shaped crystals when examined by SEM (Fig. 7). The crystals comprised only carbon $(\mathrm{C})$, oxygen $(\mathrm{O})$ and nitrogen $(\mathrm{N})$ peaks (EDX spectra) with an O:N ratio of 3:1 which is indicative of the $\mathrm{NH}_{4} \mathrm{HCO}_{3}$ salt and was confirmed by XRD. In a subsequent assessment, an 85000 $\mathrm{gNH}_{3} \mathrm{~m}^{-3}$ analogue absorbent was then run through a single fibre microporous HFMC (a PTFE fibre was used for easy potting) for approximately 5 minutes. Whilst no solid was visible within the absorbent reservoir, $\mathrm{SEM}$ analysis of the fibre revealed that $\mathrm{NH}_{4} \mathrm{HCO}_{3}$ crystals had grown in situ on the membrane surface. Ion exchange regenerant was tested in the PP HFMC and resulted in in situ crystal formation which exited the HFMC in the absorbent and was collected in a coarse filter (6-12 $\mu \mathrm{m}$ retention) for analysis (Fig. 7). The crystals were fine and amorphous in structure and were principally calcium carbonate $\left(\mathrm{CaCO}_{3}\right)$ although other cationic impurities including sodium, potassium and aluminium were also noted. In situ precipitation did not occur during return liquor assessment under identical hydrodynamic conditions to the IEX regenerant. Consequently, to enhance the likelihood for precipitation, the return liquor was recirculated in the HFMC until complete exhaustion of the absorbent. The crystalline solid was finally obtained through mild evaporation of the saturated return liquor. The EDX spectrum analysis suggested the crystal to be reasonably pure, comprising $\mathrm{C}, \mathrm{O}$ and $\mathrm{Na}$ in a ratio indicative of sodium bicarbonate $\left(\mathrm{NaHCO}_{3}\right)$.

\section{Discussion}


A key finding from this study was that the low aqueous ammonia concentration present within environmental absorbents do enable chemical enhancement of $\mathrm{CO}_{2}$ flux. The limiting aqueous $\mathrm{NH}_{3}$ concentration needed to enhance $\mathrm{CO}_{2}$ flux over water was between $100 \mathrm{gNH}_{3} \mathrm{~m}^{-3}$ and $447 \mathrm{gNH}_{3} \mathrm{~m}^{-3}$ with the upper value being indicative of the ammonium concentration reached in the IEX concentrate. This is above the ammonium concentration found in treated final effluent (around $10 \mathrm{~g}$ $\mathrm{NH}_{4}{ }^{+} \mathrm{m}^{-3}$ ) which is commonly employed as the absorbent in water scrubbers for biogas upgrading at wastewater treatment works (Persson et al., 2007). An increase in $\mathrm{pH}$ of the 10 and $100 \mathrm{~g} \mathrm{~m}^{-3}$ ammonium/ammonia absorbents did not increase $\mathrm{CO}_{2}$ flux (Fig. 2). When $\mathrm{pH}$ is increased from neutrality ( $\mathrm{pH}$ 7) to $\mathrm{pH} 11$, shifting the $\mathrm{NH}_{4}-\mathrm{N}$ equilibrium towards ca.100\% free ammonia (Equation 5, SM 1). It is therefore asserted that since the increase in available reactant (ammonia) did not increase $\mathrm{CO}_{2}$ flux, absorption within aqueous ammonia solvents below $100 \mathrm{gNH}_{3} \mathrm{~m}^{-3}$ is primarily governed by physical absorption. At aqueous ammoniacal nitrogen concentrations greater than 1000 $\mathrm{g} \mathrm{m}^{-3}$, a linear increase in $\mathrm{CO}_{2}$ flux was demonstrated with an increase in $\mathrm{pH}$ (Fig. $2 \mathrm{~b}$ ) and is indicative of the chemical enhancement provided by the increase in available free ammonia (Esquiroz-Molina et al., 2013). Significantly, for the highest aqueous $\mathrm{NH}_{4}-\mathrm{N}$ absorbent concentration evaluated (10000 $\mathrm{g} \mathrm{m}^{-3}$ ), no further increase in $\mathrm{CO}_{2}$ flux was noted as $\mathrm{pH}$ increased from $\mathrm{pH} 10$ to $\mathrm{pH} 11$ (Fig. 2a). This is analogous to the work of Esquiroz-Molina et al. (2013) and can be ascribed to the presence of an excess of free ammonia present in the reaction zone at the gas-absorbent interface at $\mathrm{pH} 10$, where the enhanced reactivity offsets the lower gaseous solubility constant thereby minimising liquid side resistance. Interestingly, in commercial aqueous ammonia packed column processes, $\mathrm{pH}$ is between 8.8 and 9.6 (Yeh et al., 2005) where the lower fraction of free ammonia available within this $\mathrm{pH}$ range can be tolerated through higher absolute $\mathrm{NH}_{4}-\mathrm{N}$ concentrations, which are typically in the range of 50000 to $100000 \mathrm{~g} \mathrm{~m}^{-3}$ (Puxty et al., 2010; Budzianowski, 2011a; Niu et al., 2012). Therefore within environmental absorbents, the reduced reactivity imposed by lower absolute $\mathrm{NH}_{4}-\mathrm{N}$ concentration can be offset by shifting the equilibrium toward free ammonia using mild $\mathrm{pH}$ correction. 
An increase in absorbent temperature did not markedly enhance $\mathrm{CO}_{2}$ flux within the environmental ammonia concentration range tested (Fig. 2). Zeng et al. (2011) also investigated the role of temperature (range $20-50{ }^{\circ} \mathrm{C}$ ) in controlling $\mathrm{NH}_{3}-\mathrm{CO}_{2}$ reaction kinetics in $2-8 \%$ wt. aqueous ammonia and similarly noted only slight enhancement of the overall mass transfer coefficient between 20 and $40^{\circ} \mathrm{C}(293-313 \mathrm{~K})$, which is within the range where forward reactions are favoured (Bai et al., 1997). The low temperature dependency potentially explains why the chilled aqueous ammonia process (temp. $1.7^{\circ} \mathrm{C}$ ) is commercially viable; the low temperature being favoured to limit ammonia slip (Valenti et al., 2009). In this study, an $\mathrm{NH}_{3}$ concentration of $0.002 \mathrm{gNH}_{3} \mathrm{~m}^{-3}$ was measured in the gas phase for the $10000 \mathrm{~g}_{\mathrm{NH} 3} \mathrm{~m}^{-3}$ absorbent at a temperature of $20^{\circ} \mathrm{C}$ which is an order of magnitude below the proposed gas phase ammonia concentration limit $\left(0.02 \mathrm{gNH}_{3} \mathrm{~m}^{-3}\right)$ for biomethane as a vehicle fuel or natural gas substitute (Persson et al., 2007; Environment Agency, 2013). Ammonia slip was demonstrated to be concentration dependent (Fig. 4) thus the low $\mathrm{NH}_{3}$ slip recorded in this study can be explained by the lower environmentally relevant ammonia concentration range studied. However, $\mathrm{NH}_{3}$ slip was also two orders of magnitude below that observed in a packed column using aqueous ammonia within a similar concentration range (Fig. 4, Niu et al., 2012). Budzianowski (2011a) postulated that the difference in $\mathrm{NH}_{3}$ slip was due to the hydraulic characteristics of each technology where the transport of $\mathrm{NH}_{3}$ to the gas-liquid interface in packed columns was reasonably turbulent whereas the preferential laminar flow regime in HFMC ( $R e=57-570$ in this study) minimises the transport of $\mathrm{NH}_{3}$ to the gas-liquid interface as $\mathrm{NH}_{3}$ transport is limited to radial diffusion from the absorbent bulk to the boundary layer. Further, stagnant $\mathrm{NH}_{3}$ within the gas-filled membrane pores, absent in column-based systems, will likely resist $\mathrm{NH}_{3}$ mass transfer from the liquid phase, which could conceivably also play a role. Therefore, HFMCs appear practically advantageous to limit ammonia slip, and when coupled with the relatively low $\mathrm{NH}_{3}$ concentration range used, enable a sufficiently clean produced gas for use.

At low gas flows, methane content in the gas outlet exceeded 98\% (Fig. 3) which meets standards for biomethane (Persson et al., 2007). An increase in gas flow rate decreased methane 
content in the outlet gas but increased $\mathrm{CO}_{2}$ flux into the receiving ammonia absorbent. In chemically reactive absorption systems, an increased gas flow often mediates solute flux (Esquiroz-Molina et al., 2013) as this permits replenishment of $\mathrm{CO}_{2}$ at the solvent-membrane interface and sustains a high bulk gas $\mathrm{CO}_{2}$ partial pressure (Zeng et al., 2013). At full scale, the balance between higher flux to reduce scale and maintenance of the outlet gas quality can be achieved through extension of reactor length (Noble and Stern, 1995). At the highest flux recorded using $10000 \mathrm{~g}_{\mathrm{NH} 3} \mathrm{~m}^{-3}$ aqueous ammonia absorbent, an overall absorption rate of $8.4 \mathrm{kmol} \mathrm{m}^{-3} \mathrm{~h}^{-1}$ was recorded. For comparison, Zeng et al. (2013) reported an overall absorption rate of $2.37 \mathrm{kmol} \mathrm{m}^{-3} \mathrm{~h}^{-1}$ from a $15 \% \mathrm{CO}_{2} \mathrm{v} / \mathrm{v}$ flue gas using $7.7 \%$ wt. aqueous ammonia in a packed column. This process comparison illustrates that analogous $\mathrm{CO}_{2}$ fluxes can be achieved with lower concentration environmental aqueous ammonia absorbents through the process intensification provided by the HFMC. Chemical enhancement within the real matrices reached a plateau at a gas-liquid ratio of 15-19 (Fig. 5). The absorbent flow regime is characteristically laminar. Consequently the $\mathrm{CO}_{2}$ loading applied at the high $\mathrm{G} / \mathrm{L}$ ratio depletes the reactant within the immediate vicinity of the gas-liquid interface and absorption rate then becomes limited by the radial diffusion of the reactant to the reactant plane (Dindore et al., 2005). Importantly, this demonstrates real environmental absorbents provide considerable enhancement of $\mathrm{CO}_{2}$ flux versus water which is the absorbent currently favoured by water utilities (Persson et al., 2007). Chemical enhancement provided by the return liquor was equivalent to that of the analogue indicating that enhancement was ostensibly a function of initial ammonia concentration. However, the IEX regenerant provided lower enhancement than an analogue of equivalent concentration which can be ascribed to the salt concentration $\left(50 \mathrm{~g} \mathrm{~L}^{-1}\right)$ which is known to reduce the physical solubility of $\mathrm{CO}_{2}$ into the absorbent (Mcleod et al., 2013). Higher chemical reactivity can be engineered into the IEX regenerant through increasing ammonia concentration which is dependent upon the zeolites cation exchange capacity (CEC), and ammonium loading (Mackinnon et al., 2003). For example, Mackinnon et al. (2003) used a higher CEC zeolite (MesoLite) to provide a regenerant 
concentration of up to $10000 \mathrm{gNH}_{4}-\mathrm{N} \mathrm{m}^{-3}$, which in this study has been shown sufficient to provide high $\mathrm{CO}_{2}$ fluxes (Fig. 3).

A $\mathrm{CO}_{2} / \mathrm{NH}_{3}$ absorbent loading of $0.046 \mathrm{~mol} \mathrm{~mol}^{-1}$ resulted from the maximum $\mathrm{CO}_{2}$ flux achieved (Fig. 3). For these absorbent loading conditions (i.e. low loading and high pH) there is general agreement that the reaction product ammonium carbamate is favoured which is three times more soluble than ammonium bicarbonate and so does not readily precipitate (Mani et al., 2006; Budzianowski, 2011a). Data from Jänecke (1929) indicates that at a $\mathrm{CO}_{2}$ loading of around 0.5 molCO molNH$_{3}^{-1}$ the equilibria shifts to favour bicarbonate (Equation 4) and ammonium ions (Equation 5) (Mani et al., 2006; Puxty et al., 2010) leading to preferential formation of ammonium bicarbonate (Equation 6). In this study, this $\mathrm{NH}_{4} \mathrm{HCO}_{3}$ precipitation route was demonstrated under high $\mathrm{CO}_{2}$ loading by bubbling $\mathrm{CO}_{2}$ directly into the analogue ammonia absorbent (Fig. 7). Importantly, sequestration of both ammonia and $\mathrm{CO}_{2}$ into precipitated $\mathrm{NH}_{4} \mathrm{HCO}_{3}$ eliminates the cost and complexity of solvent regeneration which represents a key barrier to uptake of chemical absorption (Mani et al., 2006). Following absorbent recirculation within the HFMC, ammonium bicarbonate crystals were also shown to preferentially form at the membrane surface. This is similar to the mechanism introduced by Di Profio et al. (2010) in the membrane crystallisation reactor which has been applied specifically for the enhancement of crystallisation kinetics. The authors proposed that the porous membrane surface provided cavities where solute molecules become trapped leading to localised supersaturated zones. Consequently, the use of the membrane for ammonia $\mathrm{CO}_{2}$ absorption can enable ammonium bicarbonate crystallisation at lower $\mathrm{CO}_{2}$ loadings than previously proposed in packed column investigation. The membrane's high controllability in favour of crystal growth versus nucleation can allow sufficiently sized crystals to detach due to the sheer of liquid flow and avoid scaling (Di Profio et al., 2010). However, pore wetting during operation can cause crystal formation within the fibre bore (McLeod et al., in press). This can be avoided by selection of suitably hydrophobic membranes possessing small $(<0.2 \mu \mathrm{m})$, circular pores in addition to solvents possessing high surface tension (such as highly electrolytic wastewaters). 
In the IEX regenerant $\mathrm{CaCO}_{3}$ was preferentially formed over $\mathrm{NH}_{4} \mathrm{HCO}_{3}$ due to its lower solubility (Table 1). The cations $\mathrm{Na}^{+}, \mathrm{K}^{+}$and $\mathrm{Al}^{3+}$ were also present within the precipitate due to coseparation by the cationic zeolite used. Ciambelli et al. (1985) fractionated a cationic IEX regenerant from an IEX column used for ammonium separation and identified that the $\mathrm{Ca}^{2+}$ rich (and ammonia poor) regenerant fraction was first eluted from the IEX column ahead of ammonium. It is therefore proposed that further selectivity toward $\mathrm{NH}_{4} \mathrm{HCO}_{3}$ can be imparted when using IEX by more strict regulation of the regenerant cycle to favour ammonium. However, in the return liquor, sodium bicarbonate $\left(\mathrm{NaHCO}_{3}\right)$ was preferentially precipitated due to its lower solubility constant and high $\left[\mathrm{Na}^{+}\right]$gradient. The high availability of $\left[\mathrm{Na}^{+}\right]$ions can be ascribed to the considerable sodium hydroxide addition needed to overcome the liquors buffering capacity to reach pH11. Interestingly, Hecht et al. (1990) demonstrated that equilibrium between $\mathrm{NH}_{3}$ and $\mathrm{NH}_{4}{ }^{+}$(Equation 1) can be successively re-established at low $\mathrm{pH}$ (i.e. $\mathrm{pH} 7.8$ ) following consumption of the free $\mathrm{NH}_{3}$ by solvent recirculation. Consequently, operation at lower $\mathrm{pH}$ will potentially provide more favourable conditions for ammonium bicarbonate precipitation due to the lower $\left[\mathrm{Na}^{+}\right]$gradient albeit at lower $\mathrm{CO}_{2}$ fluxes.

To establish key financial benefits from this study, revenue generation from biomethane is compared to a conventional WWTW where biogas is used in CHP to produce electricity and $\mathrm{NH}_{4}-\mathrm{N}$ is treated by nitrification. The illustrative WWTW treats $500000 \mathrm{~m}^{3} \mathrm{~d}^{-1}$ total flow, $25000 \mathrm{kgNH}_{4}-\mathrm{N} \mathrm{d}^{-1}$ (50 $\mathrm{gNH}_{4}-\mathrm{N} \mathrm{m}^{-3}$ ) and produces $3400 \mathrm{~m}^{3} \mathrm{~h}^{-1}$ raw biogas $\left(60: 40 / \mathrm{CH}_{4}: \mathrm{CO}_{2}\right)$ which generates an annual revenue of $£ 2.8 \mathrm{M} \mathrm{y}^{-1}$ following subtraction of aeration costs $\left(£ 2.9 \mathrm{M} \mathrm{y}^{-1}\right)$ which are assumed entirely attributable to nitrification (Table 3). The removal of trace $\mathrm{H}_{2} \mathrm{~S}$ and particulate impurities is assumed to be a uniform requirement for each scenario and therefore can be neglected for simplicity. However, if 100 ppmv $\mathrm{H}_{2} \mathrm{~S}$ in the biogas and a capacity of $0.3 \mathrm{~kg}$ sulfur $\mathrm{kg}^{-1}$ carbon are assumed (Rautenbach and Welsch, 1994), then approximately $1 \mathrm{t}$ of carbon media $\mathrm{y}^{-1}$ would be required for a $3400 \mathrm{~m}^{3} \mathrm{~h}^{-1}$ biogas flow. Based on an ammonium mass balance from return liquors (Jaffer et al., 2001), $22 \%$ of the biogas flow can be upgraded with ammonia ( $78 \%$ to CHP), which yields an 
increased revenue of $£ 1.3 \mathrm{M} \mathrm{y}^{-1}$. A further $£ 0.9 \mathrm{M} \mathrm{y}^{-1}$ in revenue can be achieved through including $\mathrm{NH}_{4} \mathrm{HCO}_{3}$ recovery (total $\left.f 5 \mathrm{M} \mathrm{y}^{-1}\right)$. Smaller illustrative WWTWs $\left(15000 \mathrm{~m}^{3} \mathrm{~d}^{-1}\right.$ ), typically receiving lower strength raw influent $\left(25 \mathrm{gNH}_{4}-\mathrm{N} \mathrm{m}^{-3}\right)$ and generating a $50 \%$ lower biogas flow per $\mathrm{m}^{3}$ influent, will have a reduced nitrification demand upon the ASP and possess a lower return liquor flow (assuming no imported sludge); therefore a $41 \mathrm{Kf}^{-1}$ baseline revenue via CHP is assumed. Based upon the stoichiometry of the $\mathrm{NH}_{4} \mathrm{HCO}_{3}$ product, $33 \%$ of the biogas flow may be directed towards upgrading, yielding an increased revenue of $33 \mathrm{Kf}^{-1}$ (74 Kf $\mathrm{y}^{-1}$ total). Combined use of both CHP and upgrading is considered to be most feasible at full scale as some CHP capacity is needed to deliver heat for the AD. However, it is worth noting that up to $40 \%$ of the ammonium load can be attributed to the return liquors (Johnson, 2011) hence the projected revenue (based on 22\%) can be considered conservative. Importantly, this added value could not be realised if exogenic chemicals (i.e. MEA) were used for biogas upgrading due to the high cost of chemical regeneration $\left(-2.2 \mathrm{Mf} \mathrm{y}^{-1}\right)$ (Knudsen et al., 2009).

The capital cost of the membrane installation can be determined by using the overall mass transfer coefficient $\left(\mathrm{K}_{\mathrm{L}} \mathrm{m} \mathrm{s}^{-1}\right)$ to calculate the membrane length needed to achieve a given $\mathrm{CO}_{2}$ removal from the gas phase:

$\ln \left(\frac{c_{1}}{c_{0}}\right)=\frac{-K_{L} a L}{V_{L}}$

where $L$ is the active membrane length $(m)$, a is the specific surface area for the HFMC $\left(m^{2} m^{-3}\right), V_{L}$ is the superficial liquid velocity $\left(\mathrm{m} \mathrm{s}^{-1}\right)$, and $\mathrm{c}_{0}$ and $\mathrm{c}_{1}$ are the inlet and outlet dissolved $\mathrm{CO}_{2}$ concentrations in the liquid respectively (Noble and Stern, 1995). A K $\mathrm{K}_{\mathrm{L}}$ of $1.53 \times 10^{-4} \mathrm{~m} \mathrm{~s}^{-1}$ was observed in the present study using a return liquor chemical solvent. Therefore, for a $95 \% \mathrm{CH}_{4}$ biomethane output, a membrane cost of $£ 90000$ is estimated; assuming full-scale HFMCs (Liqui-cel, $14 \times 40$ extra flow) at $40 \mathrm{f} \mathrm{m}^{-2}$ membrane area (Prasad and Sirkar, 1989). A payback time for a single module of just $15 \mathrm{~d}$ has negligible impact upon the economic benefit for the large WWTW, even when conservative module lifetimes of 0.5-3 y are considered (Prasad and Sirkar, 1989). The reduced return liquor flow of the smaller WWTW requires only a single full-scale HFMC ( $£ 15000$ ). Although 
lower revenues result in a longer time (6 months), this may be acceptable if a feasible lifetime of ca.10 y can be realised (Prasad and Sirkar, 1989).

Full upgrading, where $100 \%$ of the gas load is used for biomethane production, increases revenue to $£ 9.5 \mathrm{M} \mathrm{y}^{-1}$ due to the higher incentivisation levy for biomethane (Read and Hofmann, 2011). Based on using IEX for harvesting $\mathrm{NH}_{4}{ }^{+}$from primary effluent then $100 \%$ upgrading is theoretically achievable as mass balancing indicates the full ammonium load provides a mole ratio of 1.2:1 $\mathrm{NH}_{4}-\mathrm{N}: \mathrm{CO}_{2}$ which is within range of the stoichiometric conversion $\left(1: 1 \mathrm{NH}_{4}^{+} / \mathrm{CO}_{2}\right.$ into $\left.\mathrm{NH}_{4} \mathrm{HCO}_{3}\right)$. With the inclusion of $\mathrm{NH}_{4} \mathrm{HCO}_{3}$ recovery to $100 \%$ upgrading, revenue is estimated to increase by

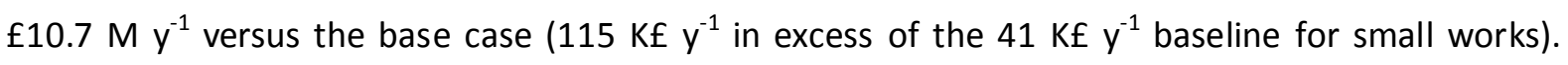
Interestingly, the added value provided by selling $\mathrm{NH}_{4} \mathrm{HCO}_{3}$ as a fertilizer and the reduction in aeration costs (for nitrification) could reduce the financial risk in investing in biomethane, where uncertainty over the future value of biomethane incentives is currently impeding implementation of biogas upgrading facilities within the UK.

For the large example WWTW an IEX bed size of approximately $6000 \mathrm{t}(1 \mathrm{Mf})$ was estimated based upon literature values for clinoptilolite media CEC and cost (Aiyuk et al., 2004), with an annual media attrition of 3\% demonstrated for full-scale IEX of municipal wastewater (Svetich, 1993). Based upon the operational IEX conditions in the present study and the maximum $\mathrm{K}_{\mathrm{L}}$ observed for the IEX regenerant solvent $\left(1.4 \times 10^{-4} \mathrm{~m} \mathrm{~s}^{-1}\right)$; a membrane installation totalling $£ 525000$ is estimated for a $95 \%$ $\mathrm{CH}_{4}$ biomethane. As a result a total payback time of $0.14 \mathrm{y}$ is anticipated for the combined IEX and membrane technologies. However, optimised operation of the IEX exchanger could reduce the regenerant flow and associated membrane capital cost in real scenarios. At a smaller scale WWTW the IEX bed capital cost approaches parity with the single full-scale HFMC required, incurring a combined capital cost of $£ 30,000$ with a payback time of $0.25 \mathrm{y}$.

\section{Conclusions}


Aqueous ammonia absorbents in the concentration range identified in ammonia rich wastewaters have been shown to enable chemically enhanced $\mathrm{CO}_{2}$ separation. Implementation of ecological solvents obviates the perceived challenges of chemical absorption where concerns regarding chemical handling and chemical cost can be precluded. The IEX regenerant provided less chemical reactivity than the return liquor due principally to the lower free ammonia concentration. The $\mathrm{CO}_{2}$ absorption rate recorded using the high concentration $\mathrm{NH}_{3}$ analogue $\left(10000 \mathrm{~g} \mathrm{~m}^{-3}\right)$ demonstrated the potential of an optimised IEX process for ecological solvent production and were superior to those identified for packed columns in the literature where higher aqueous ammonia concentrations (2-8\% wt.) are used. The enhanced absorption rate and low ammonia slip presented in this study can be attributed to the process intensification and specific hydrodynamic profile developed in HFMC technology. However, ecological solvents could still be of interest for retrofit to existing water scrubbers provided low ammonia slip can be achieved. The recovery of ammonium bicarbonate was illustrated but proved complex in real wastewater. Reaction product recovery can eliminate solvent regeneration, reduce wastewater treatment costs and provide a new revenue stream. Consequently, further investigation into more controlled methods of $\mathrm{NH}_{4} \mathrm{HCO}_{3}$ crystallisation in complex wastewaters is economically warranted and several possible options have been proposed.

\section{Acknowledgments}

The authors would like to thank the Engineering and Physical Sciences Research Council (EPSRC, V/N: 08001923), Anglian Water, Northumbrian Water, Severn Trent Water and Yorkshire Water for their financial support.

\section{References}

Aiyuk, S., Xu, H., van Haandel, A., Verstraete, W., 2004. Removal of ammonium nitrogen from pretreated domestic sewage using a natural ion exchanger. Environ. Technol. 25, 1321-1330. 
Atchariyawut, S., Jiraratananon, R., Wang, R., 2007. Separation of $\mathrm{CO}_{2}$ from $\mathrm{CH}_{4}$ by using gas-liquid membrane contacting process. J. Membr. Sci. 304, 163-172.

Bai, H., Yeh, A.C., 1997. Removal of $\mathrm{CO}_{2}$ greenhouse gas by ammonia scrubbing. Ind. Eng. Chem. Res. $36,2490-2493$.

Budzianowski, W.M., 2011. Benefits of biogas upgrading to biomethane by high-pressure reactive solvent scrubbing. Biofuels Bioprod. Bioref. 6, 12-20.

Budzianowski, W. M., 2011. Mitigating $\mathrm{NH}_{3}$ vaporization from an aqueous ammonia process for $\mathrm{CO}_{2}$ capture. Int. J. Chem. Reactor Eng. 9, A58.

Ciambelli, P., Corbo, P., Porcelli, C., Rimoli, A., 1985. Ammonia removal from wastewater by natural zeolites. I. Ammonium ion exchange properties of an Italian phillipsite tuff. Zeolites 5, 184187.

Dindore, V. Y., Brilman, D. W. F., Versteeg, G. F., 2005. Hollow fiber membrane contactor as a gasliquid model contactor. Chem. Eng. Sci. 60, 467-479.

Di Profio, G., Curcio, E., Drioli, E., 2010. Supersaturation control and heterogeneous nucleation in membrane crystallizers: Facts and perspectives. Ind. Eng. Chem. Res. 49, 11878-11889.

Environment Agency, 2013. Revised_Draft_Quality_Protocol_for_biomethane, LIFE08 ENV/UK/000208, Environment Agency, Reading, UK.

Esquiroz-Molina, A., Georgaki, S., Stuetz, R., Jefferson, B., McAdam, E.J., 2013. Influence of pH on gas phase controlled mass transfer in a membrane contactor for hydrogen sulphide absorption. J. Membr. Sci. 427, 276-282.

Hecht, V., Bischoff, L., Gerth, K., 1990. Hollow fiber supported gas membrane for in situ removal of ammonium during an antibiotic fermentation. Biotechnol. Bioeng. 35, 1042-1050.

Hernandez, M. A., Torero, M., 2013. Market concentration and pricing behaviour in the fertilizer industry: a global approach. Agricultural Econ. 44, 723-734. 
Jaffer, Y, Clark, T.A., Pearce, P., Parsons, SA., 2001. Assessing the potential of full scale phosphorus recovery by struvite formation. $2^{\text {nd }}$ International Conference on Recovery of Phosphates from Sewage and Animal Wastes, 12-14 March, Noordwijkerhout, Holland.

Jänecke, E., 1929. Über das System $\mathrm{H}_{2} \mathrm{O}, \mathrm{CO}_{2}$ und $\mathrm{NH}_{3}$. Zeitschrift fuer Elektrochemie 35, 716-728.

Knudsen, J. N., Jensen, J. N., Vilhelmsen, P. -J., Biede, O., 2009. Experience with $\mathrm{CO}_{2}$ capture from coal flue gas in pilot scale: Testing of different amine solvents. Energy Procedia 1, 783-790.

Kozak, F., Petig, A., Morris, E., Rhudy, R., Thimsen, D., 2009. Chilled ammonia process for $\mathrm{CO}_{2}$ capture 1, 1419-1426.

Kuntke, P., Smiech, K. M., Bruning, H., Zeeman, G., Saakes, M., Sleutels, T. H. J. A., Hamelers, H. V. M., Buisman, C. J. N., 2012. Ammonium recovery and energy production from urine by a microbial fuel cell. Water Res. 46, 2627-2636.

Mackinnon, I.D.R., Barr, K., Miller, E., Hunter, S., Pinel, T., 2003. Nutrient removal from wastewaters using high performance materials. Water Sci. Technol. 47, 101-107.

Makhloufi, C., Lasseugette, E., Remigy, J.C., Belaissaoui, B., Roizard, D., Favre, E., 2014. Ammonia based $\mathrm{CO}_{2}$ capture process using hollow fiber membrane contactors. J. Membr. Sci. 455, 236246.

Mani, F., Peruzzini, M., Stoppioni, P., 2006. $\mathrm{CO}_{2}$ absorption by aqueous $\mathrm{NH}_{3}$ solutions: speciation of ammonium carbamate, bicarbonate and carbonate by a ${ }^{13} \mathrm{C}$ NMR study. Green Chem. 8, 9951000.

McAdam, E. J., Pawlett, M., Judd, S. J., 2010. Fate and impact of organics in an immersed membrane bioreactor applied to brine denitrification and ion exchange regeneration. Water Res. 44, 6976.

McLeod, A., Buzatu, P., Autin, O., Jefferson, B., McAdam, E. J., In press. Controlling shell-side crystal nucleation in a gas-liquid membrane contactor for simultaneous ammonium bicarbonate recovery and biogas upgrading. J. Membr. Sci. 
McLeod, A., Jefferson, B., McAdam, E. J., 2013. Quantifying the loss of methane through secondary gas mass transport (or 'slip') from a micro-porous membrane contactor applied to biogas upgrading. Water Res. 47, 3688-3695.

Neal, C., Jarvie, H. P., Neal, M., Love, A. J., Hill, L., Wickham, H., 2005. Water quality of treated sewage effluent in a rural area of the upper Thames Basin, southern England, and the impacts of such effluents on riverine phosphorus concentrations. J. Hydrology 304, 103-117.

Nii, S., Takeuchi, H., 1992. Removal of $\mathrm{CO}_{2}$ by gas absorption across a polymeric membrane. J. Chem. Eng. Japan 25, 67-72.

Niu, Z., Guo, Y., Zeng, Q., Lin, W., 2012. Experimental studies and rate based process simulations of CO2 absorption with aqueous ammonia solutions. Ind. Eng. Chem. Res. 51, 5309-5319.

Noble, R.D., Stern, S.A., 1995. Membrane Separations Technology: Principles and applications, Elsevier, Amsterdam.

Persson, M., Jonsson, O., Wellinger, A., 2007. Task 37 - Biogas upgrading to vehicle fuel standards and grid injection, IEA Bioenergy, 8-9.

Prasad, R., Sirkar, K. K., 1989. Hollow fiber solvent extraction of pharmaceutical products: A case study. J. Membr. Sci. 47, 235-259.

Purgstaller, B. Niedermayr, A., Rinder, T., Dietzel, M., 2012. Uptake of $\mathrm{CO}_{2}$ and precipitation of $\mathrm{CaCO}_{3}$ in alkaline solutions - Mechanisms and Rates, European Mineralogical Conference 1, 639.

Puxty, G., Rowland, R., Attalla., M., 2010. Comparison of the rate of $\mathrm{CO}_{2}$ absorption into aqueous ammonia and monoethanolamine. Chem. Eng. Sci. 65, 915-922.

Rautenbach, R., Welsch, K., 1994. Treatment of landfill gas by gas permeation - pilot plant results and comparison to alternatives. J. Membr. Sci. 87, 107-118.

Read, A., Hofmann, F., 2011. Does biogas scrub up?, Materials Recycling World 2, 20-21.

Rongwong, W., Boributh, S., Assanumrungrat, S., Laosiripojana, N., Jiraratananon, R., 2012. Simultaneous absorption of $\mathrm{CO}_{2}$ and $\mathrm{H}_{2} \mathrm{~S}$ from biogas by capillary membrane contactor, $\mathrm{J}$. Membr. Sci. 392-393, 38-47. 
Shuangchen, M., Huihui, S., Bin, Z., Gongda, C., 2013. Experimental study on additives inhibiting ammonia escape in carbon capture process using ammonia method. Chem. Eng. Res. Des. $91,2775-2781$.

Svetich, R., 1993. Long-term use of clinoptilolite in the treatment of sewage at Tahoe-Truckee Sanitation Agency, Truckee, California. Zeolite '93, Occurance, Properties and Utilization of Natural Zeolites, Boise, Idaho, June 20-28.

Thornton, A., Pearce, P., Parsons, S. A., 2007. Ammonium removal from digested sludge liquors using ion exchange. Water Res. 41, 433-439.

Valenti, G., Bonalumi, D., Macchi, E., 2009. Energy and exergy analysis for the carbon capture with the chilled ammonia process (CAP). Energy Procedia 1, 1059-1066.

Yeh, J. T., Resnik, K. P., Rygle, K., Pennline, H. W., 2005. Semi-batch absorption and regeneration studies for $\mathrm{CO}_{2}$ capture by aqueous ammonia. Fuel Processing Technol. 86, 1533-1546.

Zeng, Q., Guo, Y., Niu, Z., Lin, W., 2011. Mass transfer coefficients for $\mathrm{CO}_{2}$ absorption into aqueous ammonia solution using a packed column. Ind. Eng. Chem. Res. 50, 10168-10175.

Zeng, Q., Guo, Y., Niu, Z., Lin, W., 2013. The absorption rate of $\mathrm{CO}_{2}$ by aqueous ammonia in a packed column, Fuel Processing Technol. 108, 76-81. 


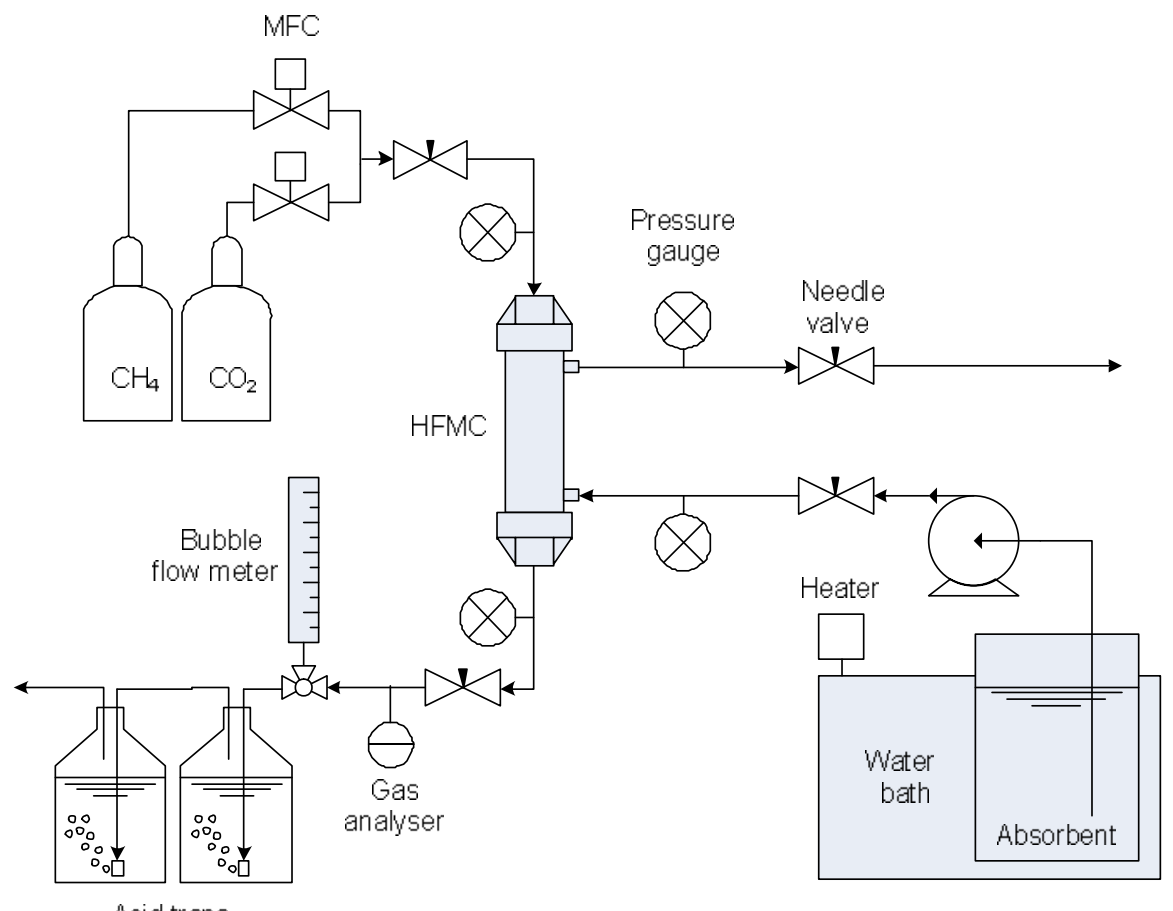

(a)

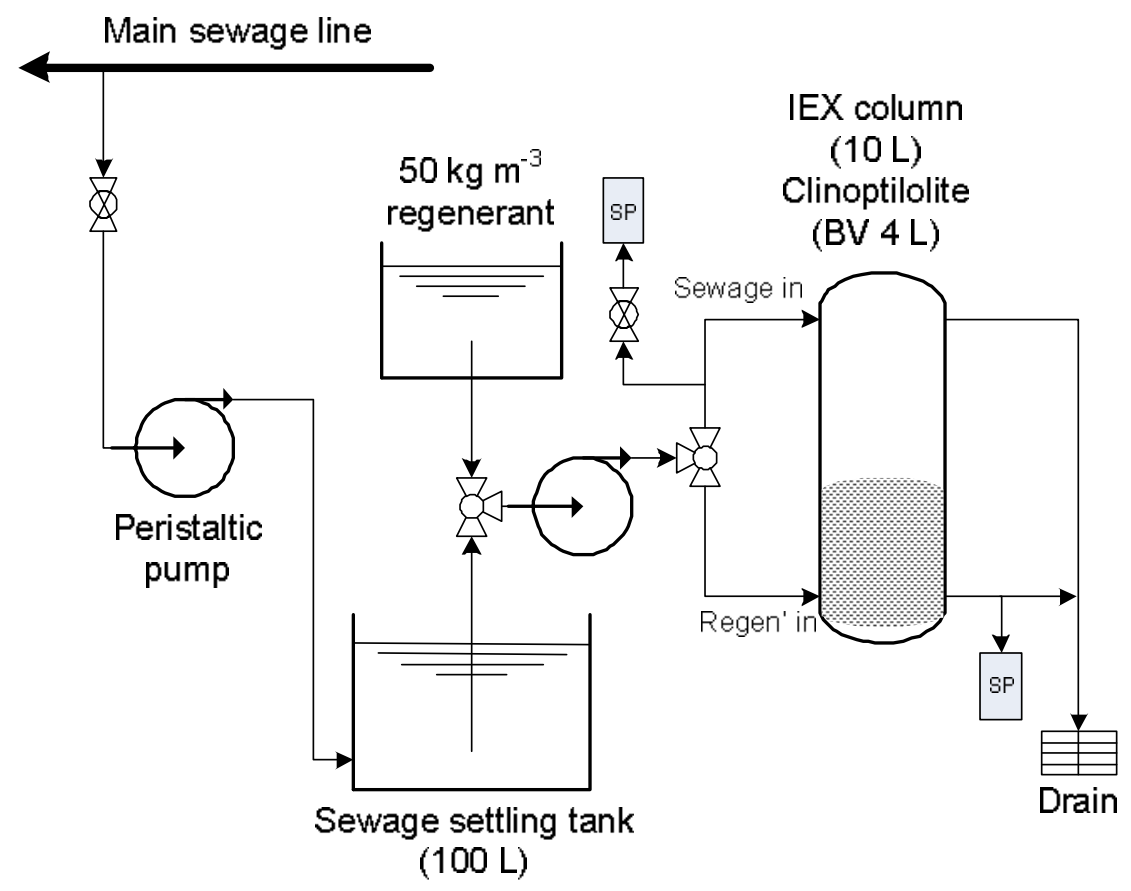

(b)

Fig. 1. (a) Set-up used for gas absorption in a polypropylene micro-porous hollow fibre membrane contactor; (b) ion exchange (IEX) column for removal of ammoniacal nitrogen ( $\left.\mathrm{NH}_{4}-\mathrm{N}\right)$ from raw sewage by clinoptilolite and subsequent production of $\mathrm{NH}_{4}-\mathrm{N}$ rich IEX regenerant. SP indicates sampling point. 


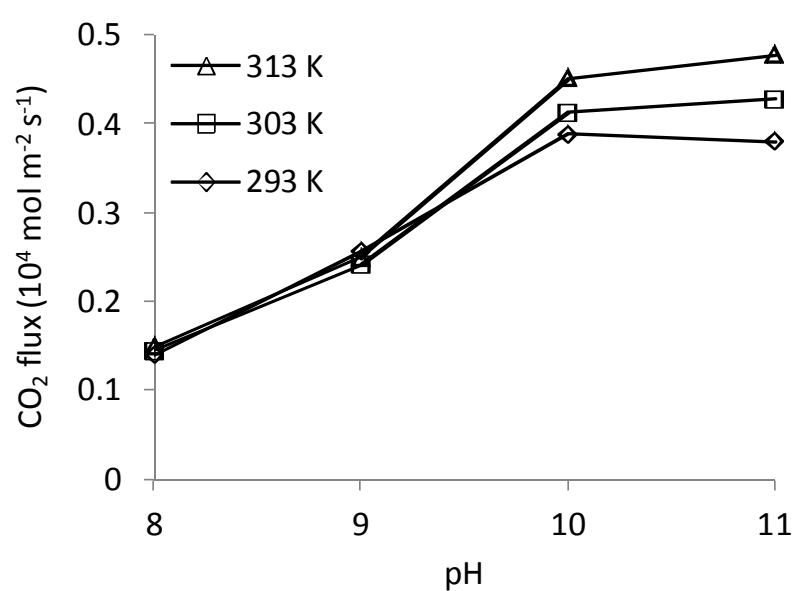

(a)

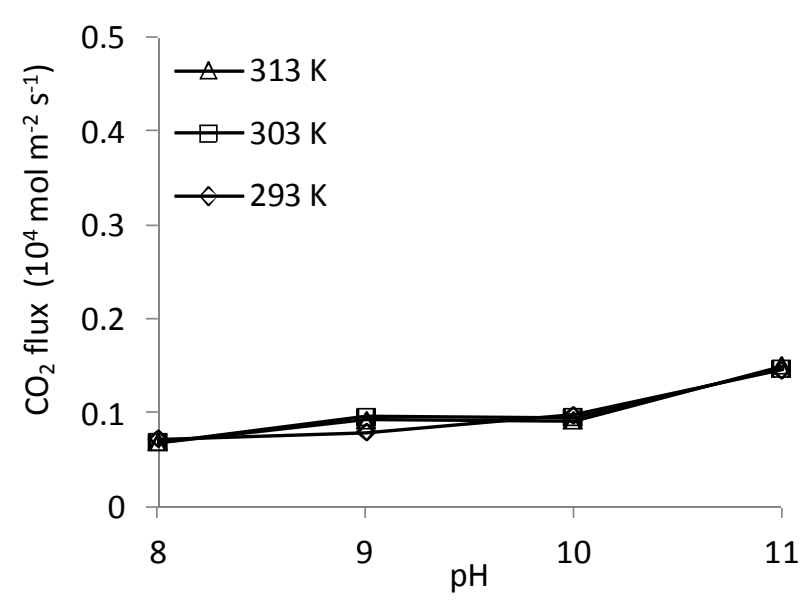

(c)

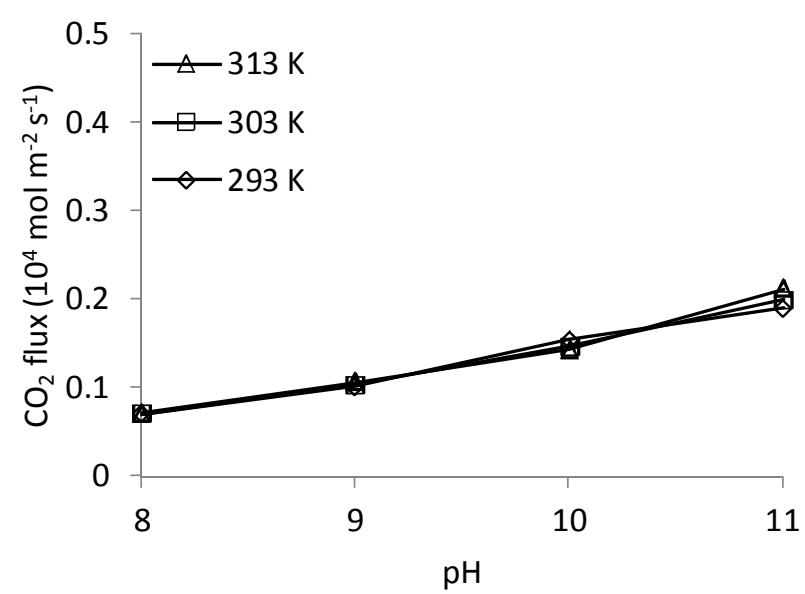

(b)

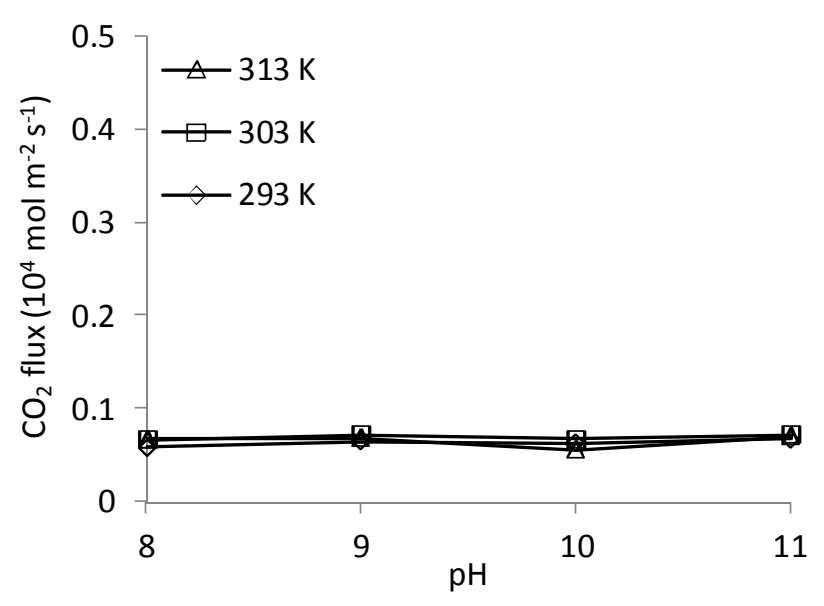

(d)

Fig. 2. Influence of $\mathrm{pH}$ and temperature upon $\mathrm{CO}_{2}$ flux $\left(\mathrm{J}_{\mathrm{CO} 2}\right)$ in analogue $\mathrm{NH}_{3}$ absorbents with concentrations of: (a) $10000 \mathrm{~g}_{\mathrm{NH} 3} \mathrm{~m}^{-3}$; (b) $1000 \mathrm{~g}_{\mathrm{NH} 3} \mathrm{~m}^{-3}$; (c) $100 \mathrm{~g}_{\mathrm{NH} 3} \mathrm{~m}^{-3}$; and (d) $10 \mathrm{~g}_{\mathrm{NH} 3} \mathrm{~m}^{-3}$ under fixed liquid and gas flow rates $\left(1.67 \times 10^{-6} \mathrm{~m}^{3} \mathrm{~s}^{-1}\right.$ and $1.25 \times 10^{-5} \mathrm{~m}^{3} \mathrm{~s}^{-1}$ respectively). 


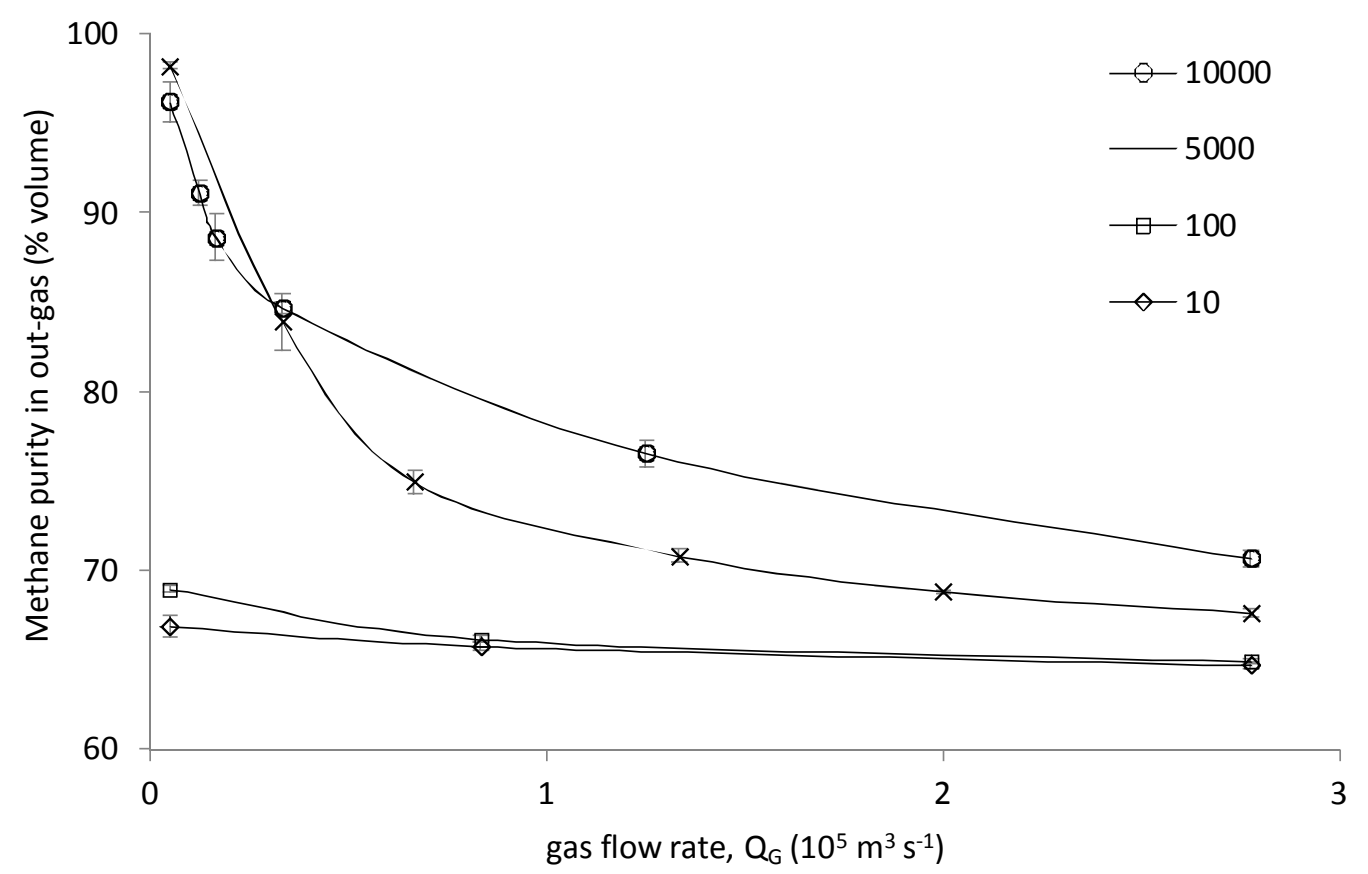

(a)

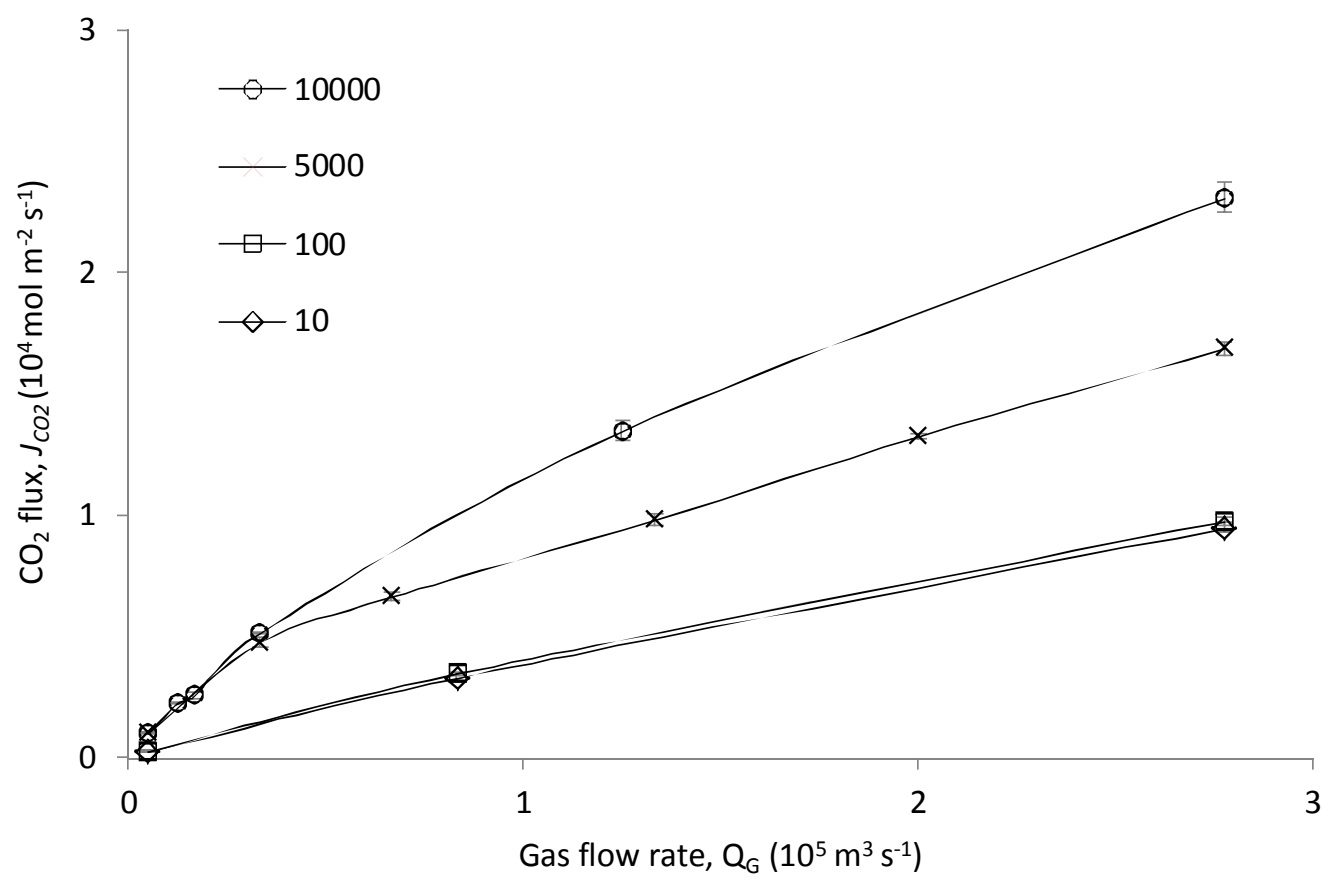

(b)

Fig. 3. Effect of variable gas flow rate $\left(Q_{G}, 0.05 \times 10^{-5}-2.8 \times 10^{-5} \mathrm{~m}^{3} \mathrm{~s}^{-1}\right)$ upon: (a) methane purity in the gas exiting the HFMC; and (b) $\mathrm{CO}_{2}$ flux. Fixed liquid flow rate $\left(Q_{L}\right) 6.7 \times 10^{-6} \mathrm{~m}^{3} \mathrm{~s}^{-1}$. Analogue absorbent $\mathrm{NH}_{3}$ concentrations ranging 10 to $10000 \mathrm{~g}_{\mathrm{NH} 3} \mathrm{~m}^{-3}$. 


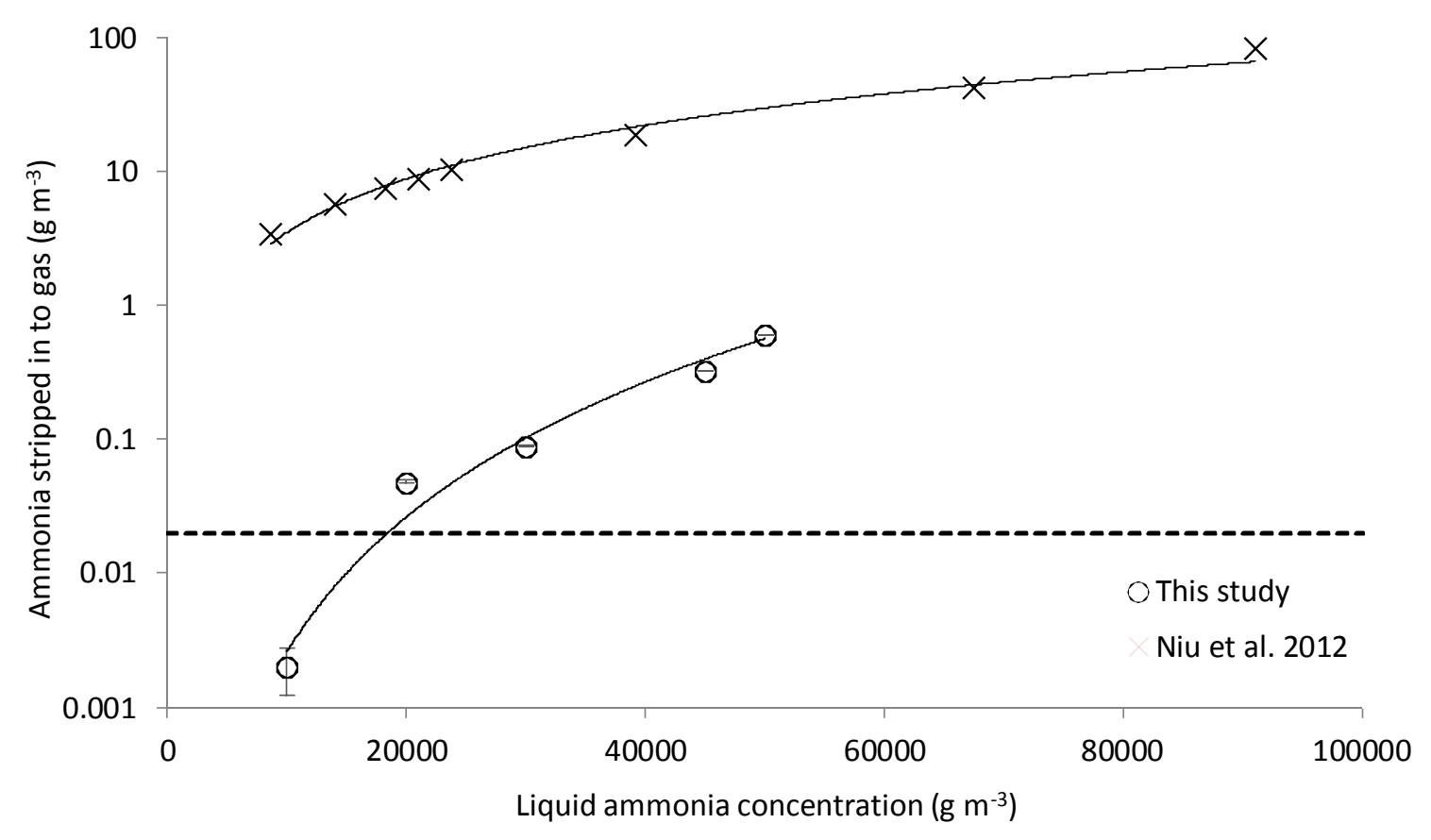

Fig. 4. Effect of increasing $\mathrm{NH}_{3}$ concentration on $\mathrm{NH}_{3}$ slip into the gas phase. Fixed liquid and initial gas flow rates $\left(Q_{L}, 1.67 \times 10^{-6} \mathrm{~m}^{3} \mathrm{~s}^{-1} ; Q_{G}, 1.25 \times 10^{-5} \mathrm{~m}^{3} \mathrm{~s}^{-1}\right)$. The dotted line represents the concentration limit for $\mathrm{NH}_{3}$ in biomethane for gas-to-grid and vehicular use $\left(0.02 \mathrm{~g} \mathrm{~m}^{-3}\right)$.

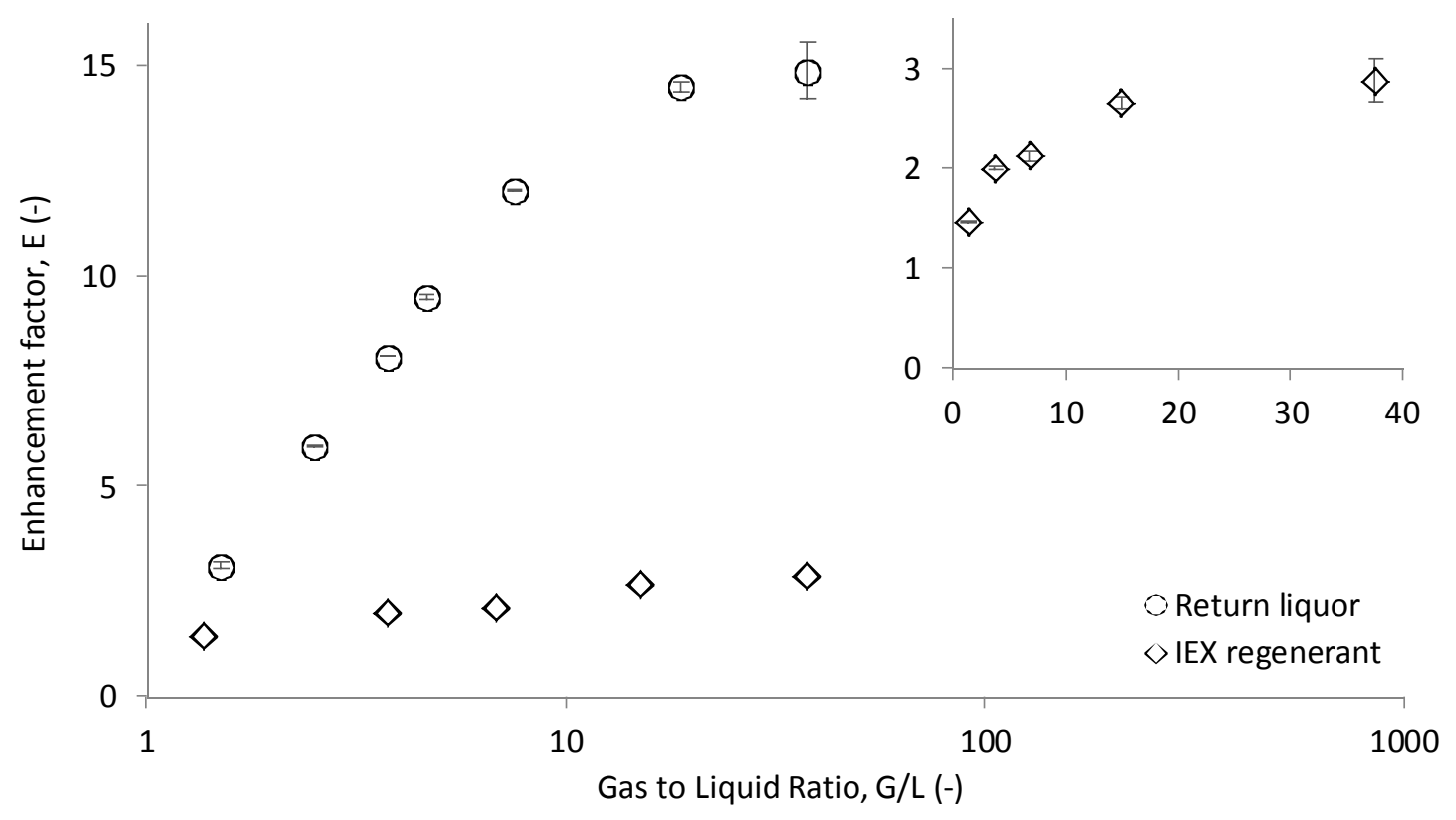

Fig. 5. Effect of variable gas-to-liquid ratio upon enhancement factor ( $E$, dimensionless), determined by ratio of $\mathrm{CO}_{2}$ flux for return liquor or IEX regenerant $\left(2325 \mathrm{~g} \mathrm{~m}^{-3}\right.$ and $447 \mathrm{~g} \mathrm{~m}^{-3}$ respectively) against $\mathrm{CO}_{2}$ flux in DI water. 


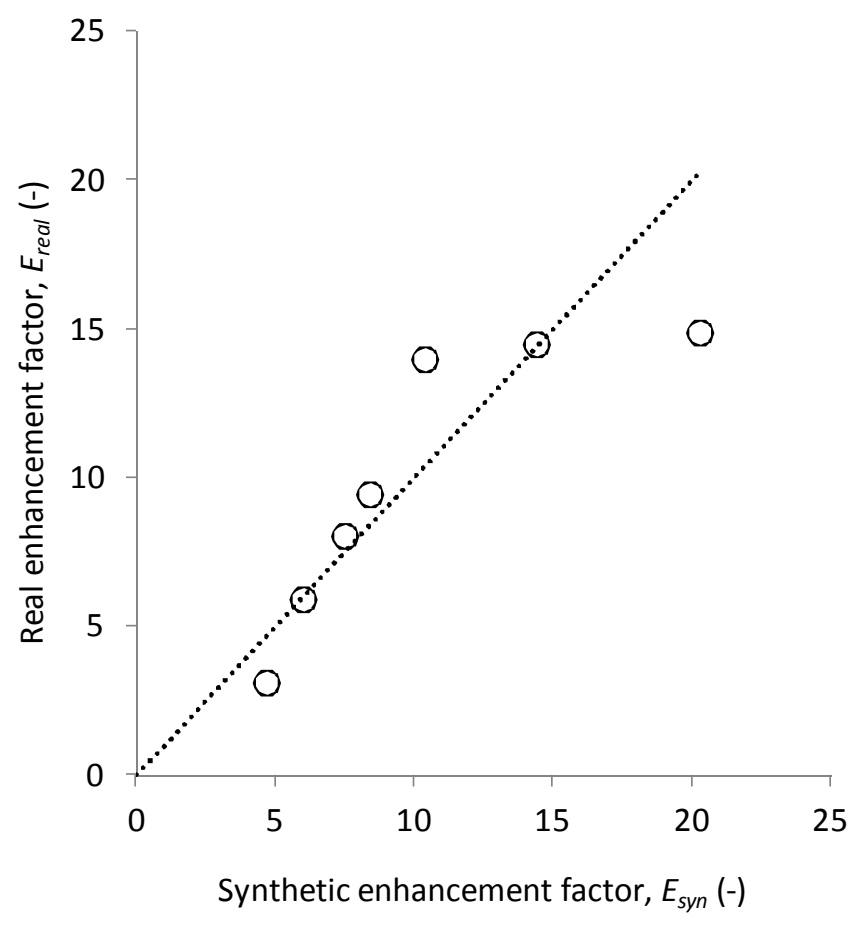

(a)

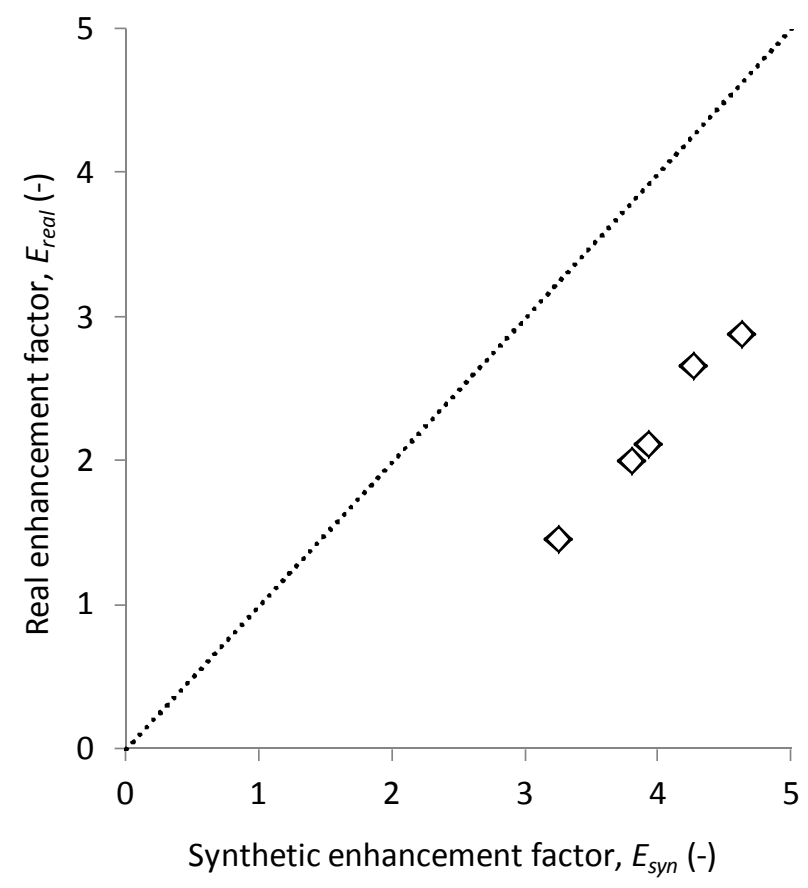

(b)

Fig. 6. Effect of variable liquid flow rate $\left(Q_{L} 0.17 \times 10^{-5}-1.7 \times 10^{-5} \mathrm{~m}^{3} \mathrm{~s}^{-1}\right)$ upon enhancement factor $(E$, dimensionless) determined by ratio of $\mathrm{CO}_{2}$ flux for (a) return liquor or (b) IEX regenerant against $\mathrm{CO}_{2}$ flux in DI water. Parity line plotted for reference (dotted line). 
SEM

(a)

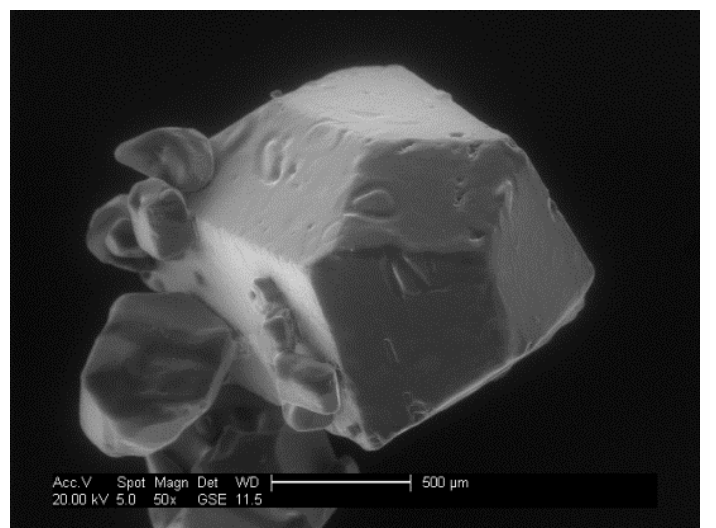

(b)

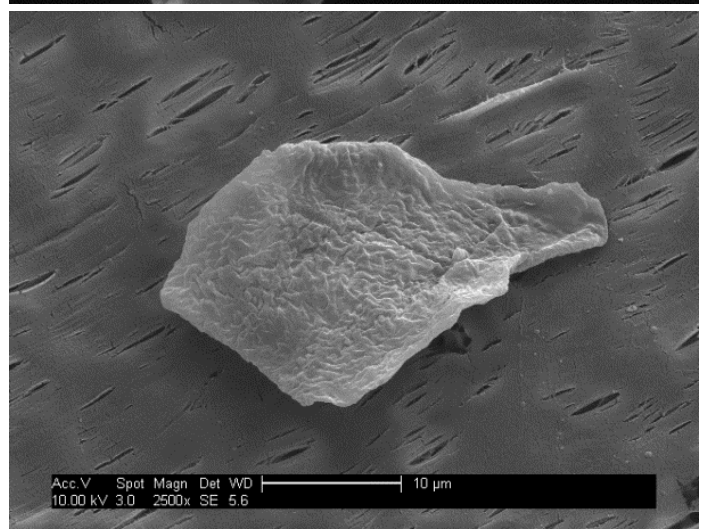

(c)
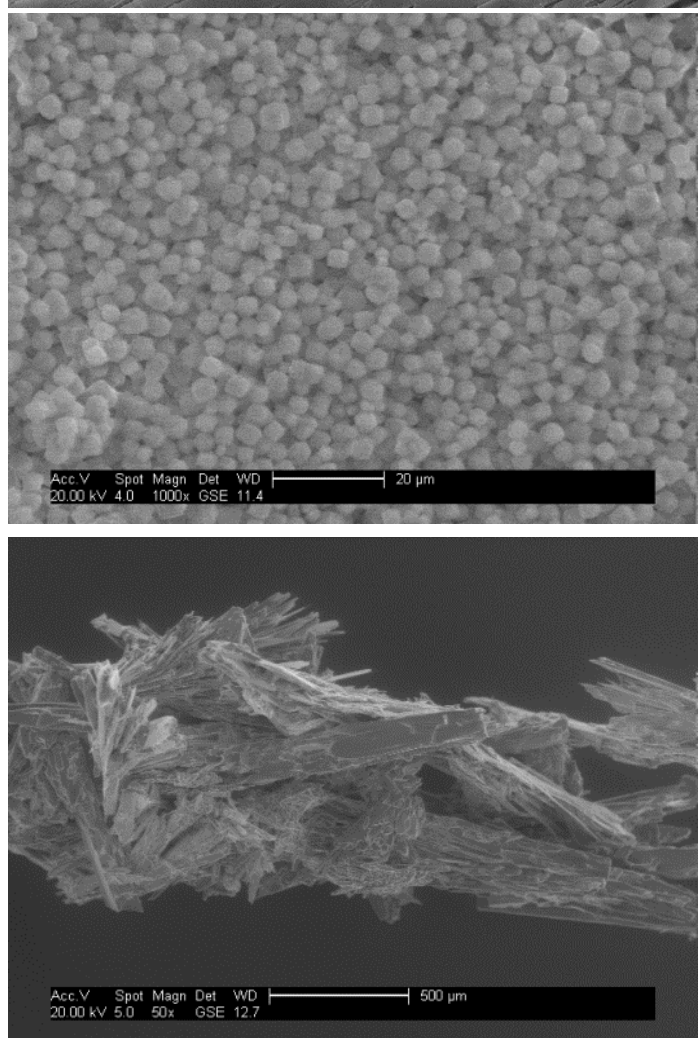
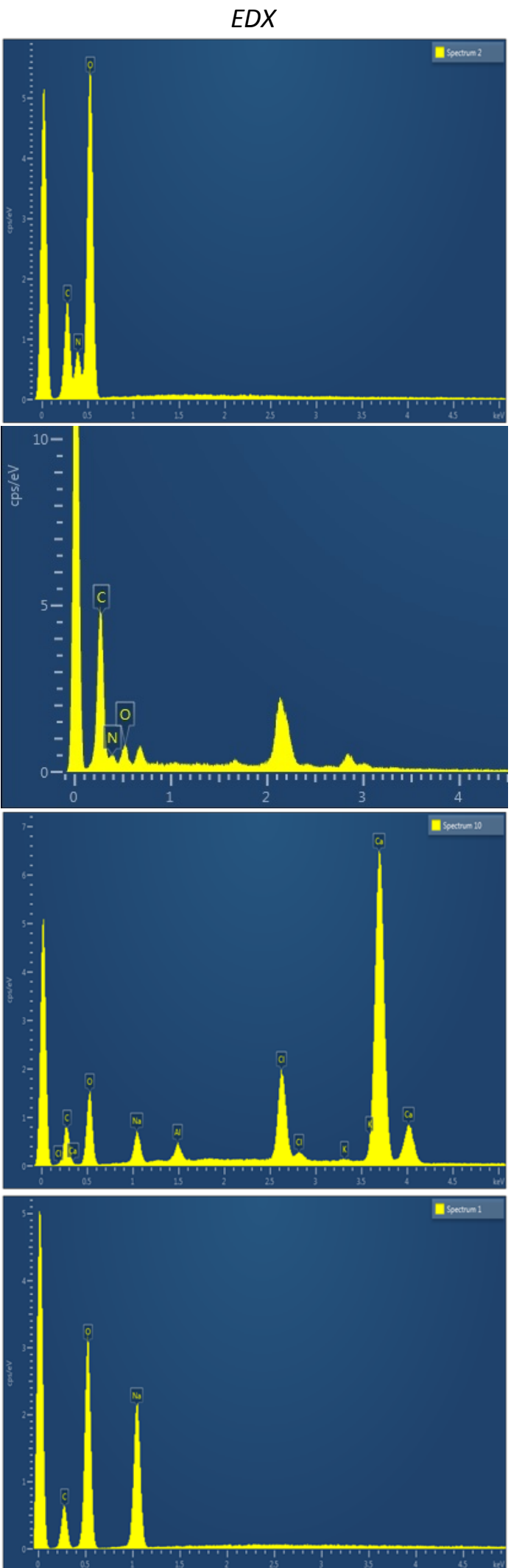

Fig. 7. Scanning electron microscope (SEM) and energy dispersive X-ray (EDX) spectra of ammonium bicarbonate formed in situ by bubbling gas through bulk solvent and by nucleation on the membrane surface (a \& b respectively), in situ calcium carbonate from IEX regenerant (c), and sodium bicarbonate from dehydration of return liquor saturated by $\mathrm{CO}_{2}(d)$. 
Table 1. Molecular masses and pure water solubilities of several binary carbonate and bicarbonate salts.

\begin{tabular}{cccccc}
\hline Name & Formula & $\begin{array}{c}\text { Molecular } \\
\text { mass } \\
\mathrm{g} \mathrm{mol}^{-1}\end{array}$ & $\begin{array}{c}\text { Water solubility } \\
\mathrm{mol} \mathrm{L}^{-1}\left(20^{\circ} \mathrm{C}\right)\end{array}$ & $\begin{array}{c}\text { Solubility } \\
\text { product } \\
\mathrm{pK}_{\text {sp }}\end{array}$ & Ref. \\
\hline $\begin{array}{c}\text { Ammonium } \\
\text { bicarbonate } \\
\text { Sodium } \\
\text { bicarbonate } \\
\begin{array}{c}\text { Calcium } \\
\text { carbonate }\end{array}\end{array}$ & $\mathrm{NH}_{4} \mathrm{HCO}_{3}$ & 79.06 & 2.24 & -0.70 & $\begin{array}{c}\text { Trypuć } \text { et al., } \\
(1998) \\
\text { Trypuć } \text { et al., } \\
(1998)\end{array}$ \\
\hline
\end{tabular}

Table 2. Characterisation of raw wastewater matrices and subsequently derived absorbents

\begin{tabular}{cccccc}
\hline Wastewater matrix & $\begin{array}{c}\mathrm{pH} \\
-\end{array}$ & $\begin{array}{c}\mathrm{NH}_{4}-\mathrm{N} \\
\mathrm{g} \mathrm{m}^{-3}\end{array}$ & $\begin{array}{c}\text { Conductivity } \\
\mathrm{mS} \mathrm{cm}^{-1}\end{array}$ & $\begin{array}{c}\mathrm{COD} \\
\mathrm{g} \mathrm{m}^{-3}\end{array}$ & $\begin{array}{c}\mathrm{TSS} \\
\mathrm{kg} \mathrm{m}^{-3}\end{array}$ \\
\hline Raw return liquor & 8.3 & 2460 & 4.9 & 8400 & 5.6 \\
Raw IEX regenerant & 7.2 & 477 & 76.6 & 1060 & \\
Filtered return liquor & 11 & 2325 & 5.1 & 7900 & 4.6 \\
Filtered IEX regenerant & 11 & 477 & 76.6 & 1060 & \\
\hline
\end{tabular}


Table 3. Characterisation of raw wastewater matrices and subsequently derived absorbents

\begin{tabular}{|c|c|c|c|c|c|c|c|}
\hline Scenario & Biogas utilisation & $\mathrm{CHP}^{\mathrm{C}}$ & Upgrade $^{c}$ & $\mathrm{NH}_{4} \mathrm{HCO}_{3}{ }^{\mathrm{d}}$ & Aeration $^{\mathrm{a}}$ & Total & Net gain ${ }^{\mathrm{e}}$ \\
\hline Baseline & $\begin{array}{l}100 \% \text { CHP } \\
0 \% \text { Upgrade }\end{array}$ & 5.7 & $\mathrm{~N} / \mathrm{a}$ & $\mathrm{N} / \mathrm{a}$ & -2.9 & 2.8 & $\mathrm{~N} / \mathrm{a}$ \\
\hline Partial upgrading ${ }^{\mathrm{g}}$ & $\begin{array}{l}78 \% \text { CHP } \\
22 \% \text { Upgrade }^{b}\end{array}$ & 4.4 & 2.1 & $\mathrm{~N} / \mathrm{a}$ & -2.4 & 4.1 & +1.3 \\
\hline Partial upgrading and recovering $\mathrm{NH}_{4} \mathrm{HCO}_{3}{ }^{\mathrm{g}}$ & $\begin{array}{l}78 \% \text { CHP } \\
22 \% \text { upgrade }^{\text {b }}\end{array}$ & 4.4 & 2.1 & 0.9 & -2.4 & 5.0 & +2.2 \\
\hline Full upgrading ${ }^{\mathrm{h}}$ & $\begin{array}{l}0 \% \text { CHP } \\
100 \% \text { Upgrade }\end{array}$ & N/a & 9.5 & $\mathrm{~N} / \mathrm{a}$ & $N / a^{f}$ & 9.5 & +6.7 \\
\hline Full upgrading and recovering $\mathrm{NH}_{4} \mathrm{HCO}_{3}{ }^{\mathrm{h}}$ & $\begin{array}{l}0 \% \text { CHP } \\
100 \% \text { Upgrade }\end{array}$ & $\mathrm{N} / \mathrm{a}$ & 9.5 & 4.0 & $N / a^{f}$ & 13.5 & +10.7 \\
\hline
\end{tabular}

$\mathrm{N} / \mathrm{a}$ - Not applicable to the specific scenario. $\mathrm{CHP}$ - Combined heat and power. ${ }^{\mathrm{a}}$ Aeration cost based solely on nitrification demand using: $4.34 \mathrm{kgO} \mathrm{kgN}^{-1}$, oxygen transfer efficiency $15 \%$, water depth $5 \mathrm{~m}$. ${ }^{\mathrm{b}}$ Biogas split based on ammonia availability in return liquor using concentration and flow from Jaffer et al. (2001). ${ }^{\mathrm{C} B i o g a s}$ costs based on Read and Hofmann (2011). ${ }^{\mathrm{d}}$ Ammonium bicarbonate wholesale value based on Hernandez et al. (2013). ${ }^{\mathrm{e}}$ Financial gain over baseline scenario (100\% $\mathrm{CHP}$ plus nitrification). ${ }^{\mathrm{f}}$ Assumes $100 \% \mathrm{NH}{ }_{4}$ utilisation for biogas upgrading, where mass balance across the example works demonstrates a mole ratio of $1.2: 1 \mathrm{NH}_{4}{ }^{+}-\mathrm{N}^{-} \mathrm{CO}_{2}$ which indicates an excess of $\mathrm{NH}_{4}{ }^{+} \mathrm{N}_{\text {given }}$ the stoichiometric conversion of $\mathrm{NH}_{4}{ }^{+}$ into $\mathrm{NH}_{4} \mathrm{HCO}_{3}$ is $1: 1 .{ }^{\mathrm{g}}$ Using return liquors. ${ }^{\mathrm{h}}$ Using IEX regenerant following wastewater treatment. 